\title{
Standardized ileal digestible methionine and cysteine requirement for broilers
}

\author{
J.W. Spek \\ Wageningen Livestock Research
}

CVB Documentation report nr. 63

June 2018

https://doi.org/10.18174/455513

Wageningen Livestock Research

P.O. Box 338

$6700 \mathrm{AH}$ Wageningen

The Netherlands 


\section{๑) Federatie Nederlandse Diervoederketen 2017}

No part of this edition may be copied, photocopied, reproduced, translated or reduced to any electronic medium or machine-readable form, in whole or in part, without specific written permission of the Federatie Nederlandse Diervoederketen (info@diervoederketen.nl).

All copyrights and database rights with respect to this publication are expressly reserved. Nothing in this publication may be reproduced, copied, retrieved, made public or re-used or made available in any way whatsoever to third parties by way of printing, photocopying, microfilm or in any other way unless the Federatie Nederlandse Diervoederketen has given express written permission to do so. This publication has been compiled with great care; however, the Federatie Nederlandse Diervoederketen and Wageningen Livestock Research cannot be held liable in any way for the consequences of using the information in this publication. 


\section{Preface}

In 2017 a new Table has been introduced called; Table 'Standardized ileal digestibility of amino acids in feedstuffs for poultry' and has been described in the CVB Documentation report nr. 61 . As a feed evaluation system has two pillars - the supply of nutrients by the diet on the one hand and the requirement for these nutrients by the animals on the other hand (both expressed in the same units) - it was also necessary to also update and express the amino acid requirements on a standardized ileal digestibility (SID) basis.

Therefore a large meta-analysis dataset was constructed from studies in which amino acid requirements in broilers were estimated. The SID amino acid concentrations of the diets used in the studies were recalculated based on the new CVB SID amino acid Table (CVB Documentation report nr. 61) and requirements of SID amino acids were subsequently estimated. The results of this meta-analysis for standardized ileal digestible methionine and cysteine (SID-M+C) are presented in the present CVB Documentation report. Compared to the former CVB apparent faecal digestible $M+C$ recommendation for broilers described in CVB Documentation report nr. 18 and published in 1996 the present established SID-M+C amino acid recommendations for broilers are:

1. Based on a substantial larger dataset of requirement studies

2. Based on studies with modern broiler types in the period $1989-2017$

3. Based on standardized ileal digestible amino acid values in feedstuffs instead of apparent faecal digestible amino acid values.

The in this report estimated requirement of SID-M+C will be incorporated in the Dutch CVB Tabellenboek Veevoeding Pluimvee 2018 and in the English version CVB Table Poultry Nutrition 2018.

This study was guided and assessed by the Technical Committee of CVB

Wageningen, June 2018

J.W. Spek 


\section{Members of the Technical Committee of the CVB}
M. Rijnen (chair)
J. Fledderus
B. Boswerger
A. Dijkslag
H. van Laar
K. Geerse
D. van Manen
J. van der Staak
H. Korterink
A. van de Ven
C. van Vuure
G. van Duinkerken

J.W. Spek
Nederlandse Vereniging Diervoederindustrie (Nevedi) Nederlandse Vereniging Diervoederindustrie (Nevedi) Nederlandse Vereniging Diervoederindustrie (Nevedi) Nederlandse Vereniging Diervoederindustrie (Nevedi) Nederlandse Vereniging Diervoederindustrie (Nevedi) Nederlandse Vereniging Diervoederindustrie (Nevedi) Overleggroep Producenten Natte Veevoeders (OPNV) Land- en Tuinbouworganisatie Nederland (LTO) Nederlandse Vereniging van Handelaren in Stro, Fourages en Aanverwante Producten (HISFA) Nederlandse Vereniging Diervoederindustrie (Nevedi) MVO, ketenorganisatie voor oliën en vetten Wageningen Livestock Research, Dept. Animal Nutrition, Wageningen

Wageningen Livestock Research, Dept. Animal Nutrition, Wageningen 


\section{Contents}

Table of Contents $\quad$ Page

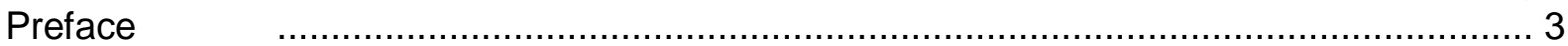

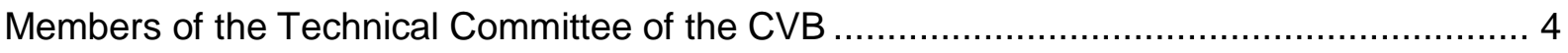

Contents $\quad$.

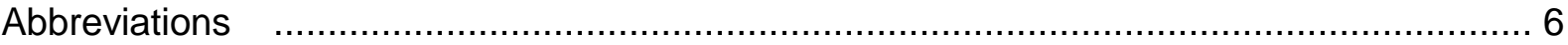

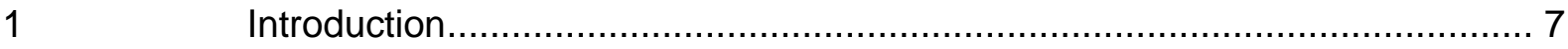

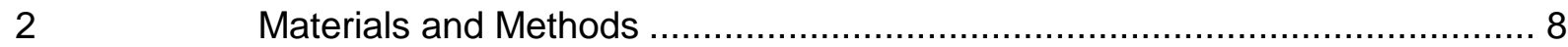

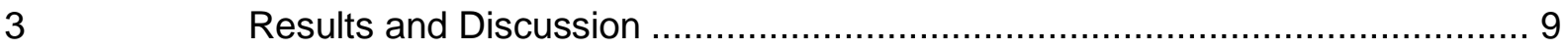

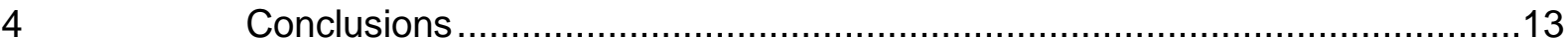

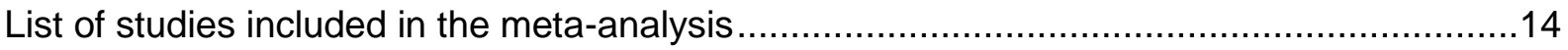

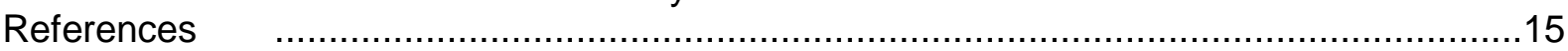

Appendix A. Relationship between dietary SID-M+C supply and performance parameters

FCR and BWG for the various titration trials. .........................................16

Appendix B. SID-M+C model estimates using the quadratic broken-line model for minimum

FCR and maximum BWG ................................................................4 


\section{Abbreviations}

$\begin{array}{ll}\text { AA } & \text { Amino acids } \\ \text { AFD } & \text { Apparent faecal digestible } \\ \text { ARG } & \text { Arginine } \\ \text { BWG } & \text { Body weight gain } \\ \text { CP } & \text { Crude protein } \\ \text { FCR } & \text { Feed conversion ratio } \\ \text { ILE } & \text { Isoleucine } \\ \text { LYS } & \text { Lysine } \\ \text { ME } & \text { Metabolic energy } \\ \text { MET } & \text { Methionine } \\ \text { M+C } & \text { Methionine plus Cysteine } \\ \text { N } & \text { Number } \\ \text { R } & \text { Coefficient of determination } \\ \text { Req } & \text { Requirement } \\ \text { SID } & \text { Standardized ileal tract digestible } \\ \text { Std. Dev. } & \text { Standard deviation } \\ \text { Std. Err. } & \text { Standard error } \\ \text { THR } & \text { Threonine } \\ \text { TRP } & \text { Tryptophan } \\ \text { VAL } & \text { Valine }\end{array}$




\section{Introduction}

In 2012 a large meta-analysis was carried out by Veldkamp and others in order to determine the dietary requirements for standardized ileal tract digestible (SID) amino acids (AA) for broilers. This study resulted in a report published by Veldkamp et al. (2016). Before the start of this meta-analysis another large meta-analysis was carried out in order to determine the SID-AA levels for the various feed ingredients. This meta-analysis resulted in a CVB table with SID-AA concentrations for the various feed ingredients and this Table was used by Veldkamp et al. (2016) in order to recalculate the dietary SID-AA levels for the individual AA titration studies in order to estimate AA requirements. However, in 2017 this CVB Table has been updated with new data published in the years between 2012 and 2017 as there were questions about the SID cysteine digestibility value for soybean meal. As a result, not only the SID-AA values for soybean meal have been updated but also for other feedstuffs. As a consequence it was necessary to recalculate all the diets used in the AA titration studies that Veldkamp et al. (2016) used to determine AA requirements. In this CVB documentation report the results of estimated dietary SID methionine and cysteine (SID-M+C; \%) requirements are presented that are based on the new Table values as presented in CVB documentation report nr. 61. Furthermore, the dataset used by Veldkamp et al. has been extended with new studies that were not included in the study of Veldkamp et al.. This resulted in a dataset that is substantially larger than the dataset used by Veldkamp. The SID$\mathrm{M}+\mathrm{C}$ requirements of the individual titration trials were estimated using a quadratic broken line model. This model was also used in estimation of SID-lysine requirements in the individual lysine titration trials as described in CVB documentation report nr. 62. 


\section{Materials and Methods}

Methionine and cystine titration studies were selected from literature $(1989-2017)$ in which only the dietary $\mathrm{M}+\mathrm{C}$ content was varied by means of addition of graded levels of dietary synthetic methionine and/or cysteine. Furthermore, only those titration studies were selected in which non-test apparent digestible amino acid levels of the basal diet (diet with the lowest $\mathrm{M}+\mathrm{C}$ content) did not come below $10 \%$ of the recommended CVB (2012) levels and where dietary digestible $\mathrm{M}+\mathrm{C}$ levels of the basal diets where at least $20 \%$ below the recommended CVB (2012) level. Furthermore, performance characteristics such as body weight gain (BWG: $g / d$ ) and feed conversion ratio (FCR; $g$ feed : $g$ BWG) had to be recorded and information with respect to dietary composition, sex, age of the broilers and duration of the experiment had to be provided in the studies.

Requirements were estimated using a quadratic broken-line model. The quadratic broken line model is as follows:

If $(\operatorname{SID}-M+C(\%)<R)$ then BWG or FCR $=L+U \times(R-S I D-M+C)^{\wedge 2}$;

Else BWG or $F C R=L+U \times 0$;

Where:

$\mathrm{L}=$ plateau value for $\mathrm{BWG}$ or $\mathrm{FCR}$

$\mathrm{R}=$ break-point value for SID-M+C (\%)

$U$ = slope value, representing the increase in BWG or decrease in FCR per unit increase in dietary SID-M+C.

As $M+C$ requirements are normally expressed as a percentage of lysine (LYS) requirement the estimated SID-M+C requirements of the individual $M+C$ titration trials were expressed as a percentage of SID-LYS level. The SID-LYS level was in a number of cases the SID-LYS level used in the $M+C$ titration studies. However, in a number of cases the SID-LYS levels used in the $M+C$ titration studies were larger than the SID-LYS requirements as predicted from the factors mean age of the birds and the dietary ME value as described in the prediction formulas F.5. and F.9. in CVB documentation report nr. 62. In those cases where the SID-LYS levels used in the $M+C$ titration studies were larger than the SID-LYS requirements as predicted from the prediction formula for SID-LYS requirements in CVB documentation report nr. 62 the predicted SID-LYS requirement levels using formulas F.5. (for BWG) and F.9. (for FCR) were used for the calculation of the SID M+C : SID-LYS ratios (SID-M+C:LYS) of the individual experiments.

Via the PROC MIXED procedure of SAS the estimated SID-M+C:LYS requirements for BWG and FCR were regressed against factors such as age, sex and the dietary factors CP, ME and $\mathrm{CP}: \mathrm{ME}$ ratio with study effect included as a random factor. Furthermore, non-test SIDAA : SID-LYS ratios were calculated and it was checked whether some of the non-test SID AA negatively affected the estimated SID-M+C:LYS requirement levels. 


\section{Results and Discussion}

In Table 1 a summary of the total dataset is given. The dataset consisted of 15 studies with in total 60 titration trials and 328 observations.

Table 1. Summary of the total dataset

\begin{tabular}{lrrrrr}
\hline & N & Mean & $\begin{array}{l}\text { Std. } \\
\text { Dev. }\end{array}$ & Minimum & Maximum \\
\hline ME Recalculated (kcal/kg) & 328 & 3035 & 123.0 & 2785 & 3360 \\
ME Publication (kcal/kg) & 328 & 3114 & 103.9 & 2950 & 3370 \\
CP Recalculated (\%) & 328 & 21 & 1.6 & 18 & 28 \\
CP Publication (\%) & 328 & 21 & 1.7 & 17 & 28 \\
Year & 328 & 2007 & 7.1 & 1989 & 2016 \\
Starting age (d) & 328 & 10 & 9.1 & 1 & 36 \\
Duration (d) & 328 & 14 & 5.3 & 6 & 21 \\
finishing age (d) & 328 & 24 & 11.9 & 7 & 42 \\
Mean age (d) & 328 & 17 & 10.2 & 4 & 39 \\
BWG (g/d) & 328 & 49.3 & 24.16 & 7.7 & 125.8 \\
FCR & 328 & 1.591 & 0.3821 & 1.001 & 2.778 \\
\hline
\end{tabular}

In Appendix $A$ for each titration trial the relationship between dietary SID-M+C supply and FCR and the relationship between dietary SID-M+C and BWG is presented graphically together with the estimated requirement values. In Appendix B the estimated quadratic broken-line model parameters for each titration trial is given.

For a number of titration trials (13 titration trials for FCR and 14 titration trials for BWG) it was not possible to estimate reliable or unique SID-M+C requirements.

The estimated SID-M+C:LYS requirement ratios for BWG and FCR were not significantly related to sex and age. Furthermore, dietary protein concentration was significantly related to the estimated SID-M+C:LYS requirement for BWG but not to the estimated SID-M+C:LYS requirement for FCR. Dietary ME was significantly and positively related to SID-M+C:LYS requirement ratios for both BWG and FCR. The ratio of dietary protein to dietary ME could not explain more variation in SID-M+C:LYS requirement than dietary ME content alone. The amount of variation in estimated SID-M+C:LYS requirement for BWG explained by dietary protein content was low $\left(R^{2}=0.118\right)$ and also the amount of variation in SID-M+C:LYS for BWG and FCR explained by dietary ME content was low $\left(R^{2}=0.283\right.$ and 0.125 for, respectively, BWG and FCR).

Because only a marginal amount of variation in SID-M+C:LYS requirement for BWG and FCR could be explained by factors such as dietary protein and dietary ME and because the factors sex and age were not significant in explaining variation in SID-M+C:LYS requirements for BWG and FCR it was concluded that it is undesirable to predict SID-M+C:LYS requirement ratios based on factors such as age, sex, dietary protein content and dietary ME content.

The average estimated SID-M+C:LYS ratios for the remaining 47 estimated SID-M+C:LYS requirement values for FCR and the 46 estimated SID-M+C:LYS requirement values for BWG were:

SID-M+C:LYS for BWG $=71.4 \pm 9.55 \%$ (average \pm Std. Dev.)

SID-M+C:LYS for FCR $=71.7 \pm 11.81 \%($ average \pm Std. Dev. $)$

Furthermore, there were some outlier SID-M+C requirement estimates that deviated more than two standard deviations from the average estimated SID-M+C requirement estimates. These were 2 estimated values from the study of Fatufe and Rodehutscord (2005) (low 
estimated SID-M+C requirement values for both BWG and FCR), 2 estimated requirement values from the study of Dozier and Mercier (2013), and one estimated requirement value from the study of Lumpkins et al. (2007).

When removing these outlier values the average estimated SID-M+C:LYS requirement ratios for the remaining 43 FCR trials and 42 BWG trials were:

SID-M+C:LYS for BWG $=71.8 \pm 7.36 \%$ (average \pm Std. Dev.)

SID-M+C:LYS for FCR $=72.1 \pm 8.29 \%$ (average \pm Std. Dev.)

There were some studies that contained a large number of titration trials whereas some studies contained only one titration trial. This results in average calculated SID-M+C:LYS requirement ratios for BWG and FCR that were strongly influenced by the studies containing a large number of titration trials. In order to weigh the estimated SID-M+C:LYS ratios from each study equally it is necessary to take into account the effect of study. This was done (using the PROC MIXED procedure of SAS and by including study as a random effect in the model) and then the estimated SID-M+C:LYS ratios for BWG and FCR became:

SID-M+C:LYS for BWG $=71.9 \pm 2.61 \%$ (model estimate \pm Std. Err. $)$

SID-M+C:LYS for FCR $=72.1 \pm 3.22 \%$ (model estimate \pm Std. Err.)

In Table 2 the dietary non-test SID-AA : SID-LYS requirement ratios for FCR and BWG are given together with the recommended CVB apparent faecal digestible (AFD) ratios. Results in Table 2 show that on average the estimated SID-M+C requirement estimates were not negatively impacted by limiting non-test $A A$ levels although in a number of trials some nontest AA levels could have had a negative impact on estimated SID-M+C levels as a comparison between recommended CVB ratios and minimal ratios for both FCR and BWG observed in this study show. However, a visual inspection of graphs in which the various SID-AA:LYS ratios were plotted against estimated SID-M+C:LYS requirements did show only one study with two titration trials (study of Fatufe and Rodehutscord, 2005) in which the estimated SID-M+C:LYS requirements substantially differed from the rest of the SID-M+C requirement estimates combined with suboptimal low ratios of non-test $A A: L Y S$ ratios of TRP:LYS, ILE:LYS en LEU:LYS.

Table 2. Dietary non-test SID-AA : SID-LYS ratios.for FCR and BWG and compared to the recommended (Rec.) CVB apparent faecal digestible (AFD) ratios.

\begin{tabular}{|c|c|c|c|c|c|c|c|c|c|}
\hline \multirow[b]{2}{*}{ Ratio } & \multirow{2}{*}{$\begin{array}{l}\text { Rec. } \\
\text { CVB } \\
\text { AFD } \\
\text { ratio }\end{array}$} & \multicolumn{4}{|c|}{ FCR } & \multicolumn{4}{|c|}{ BWG } \\
\hline & & Mean & $\begin{array}{l}\text { Std. } \\
\text { Dev. }\end{array}$ & Min & Max & Mean & $\begin{array}{l}\text { Std. } \\
\text { Dev. }\end{array}$ & Min & Max \\
\hline THR:LYS & 65 & 63 & 5.0 & 46 & 70 & 64 & 4.9 & 46 & 70 \\
\hline TRP:LYS & 16 & 18 & 2.9 & 12 & 21 & 18 & 3.0 & 12 & 21 \\
\hline ILE:LYS & 66 & 70 & 8.5 & 43 & 80 & 70 & 8.4 & 43 & 80 \\
\hline ARG:LYS & 105 & 115 & 14.0 & 88 & 177 & 115 & 14.0 & 88 & 177 \\
\hline VAL:LYS & 80 & 79 & 6.5 & 60 & 89 & 80 & 6.4 & 60 & 88 \\
\hline
\end{tabular}

The exercise of estimating SID-M+C:LYS requirement ratios for BWG and FCR in which each study is equally weighted was now repeated but in this case the results of the study of Fatufe and Rodehutscord (2005) were excluded. When this was done (by using the PROC MIXED procedure of SAS and including study as a random effect in the model) the estimated SID-M+C:LYS requirement ratios for BWG and FCR became:

SID-M+C:LYS for BWG $=73.2 \pm 1.70 \%$ (model estimate \pm Std. Err.) SID-M+C:LYS for FCR $=74.3 \pm 2.28 \%$ (model estimate \pm Std. Err.) 
It furthermore appeared that the estimated SID-M+C:LYS ratios were related to the model estimated increase in BWG per unit increase in dietary SID-M+C as shown in Figure 1. Figure 1 shows a model estimated SID-M+C:LYS plateau ratio of around $66 \%$ at steep increases in BWG per unit increase in dietary SID-M+C. This ratio increases up to a estimated SID-M+C:LYS ratio of $95 \%$ at very low model estimated increases in BWG per unit increase in dietary SID-M+C. The model estimated increase in BWG per unit increase in dietary SID-M+C was also related to the difference between the basal level of BWG and the estimated maximum BWG $(=\mathrm{L})$ as shown in Figure 2 indicating that choice of the basal level of dietary SID-M+C in a titration study affects the estimated SID-M+C:LYS ratio (the lower the basal level, the higher the difference between the basal level of BWG and the estimated maximum BWG $(=L)$ and the lower the estimated SID-M+C:LYS ratio). These relationships suggest that a SID-M+C:LYS ratio of around $66 \%$ is the absolute minimum requirement for SID-M+C resulting in a strong impairment of BWG below $66 \%$ whereas small improvements in BWG may be expected at SID-M+C:LYS ratios above $66 \%$.

It can be concluded that variation in estimated SID-M+C:LYS ratios was not sufficiently related to sex, age and dietary energy and protein to develop a prediction formula for SID$M+C: L Y S$ based on one of the just named factors. It is furthermore concluded that part of the variation in estimated SID-M+C:LYS ratios is related to the model estimated steepness of the increase in BWG per unit increase in dietary SID-M+C and that this steepness is affected by the choice of the basal level of $\mathrm{M}+\mathrm{C}$ in the diet (the lower the basal level, the higher the difference between BWG at the basal level and the estimated plateau level, the steeper the increase in in BWG per unit increase in dietary SID-M+C, and the lower the estimated SID$M+C: L Y S$ ratio).

It is therefore difficult to decide what the optimal dietary SID-M+C:LYS ratio is. Because of this difficulty it might be most prudent to base the dietary SID-M+C:LYS ratio recommendation on the complete dataset of SID-M+C trials and correct for a (random) study effect. This results in the following recommendations:

SID-M+C:LYS for BWG $=73.2 \pm 1.70 \%$ (model estimate \pm Std. Err.) SID-M+C:LYS for FCR $=74.3 \pm 2.28 \%$ (model estimate \pm Std. Err.) 


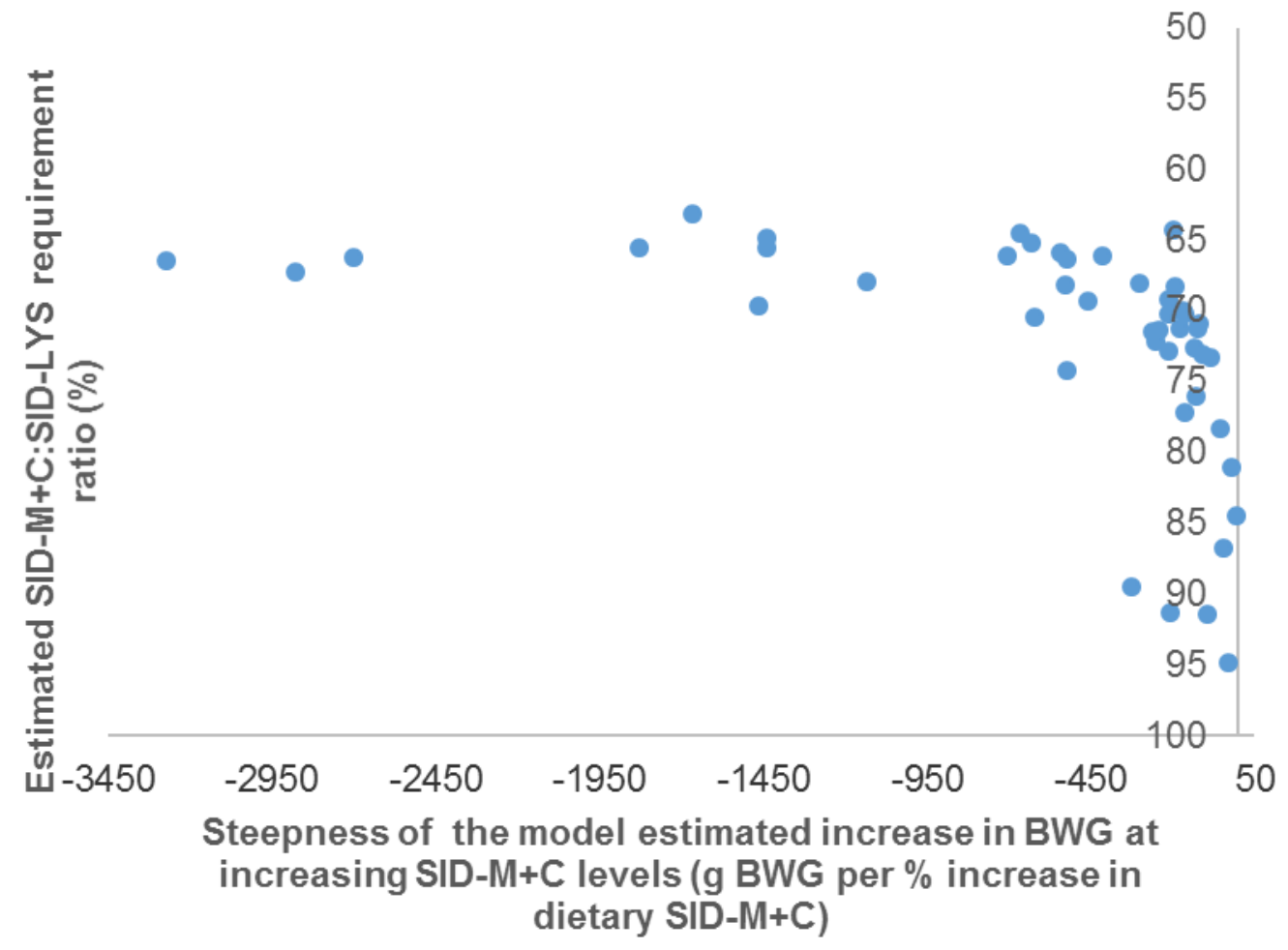

Figure 1. Relationship between the estimated SID-M+C:SID-LYS requirement ratio (\%) and the model estimated steepness of the increase in BWG at increasing dietary SID-M+C levels (g BWG per percent increase in dietary SID-M+C).

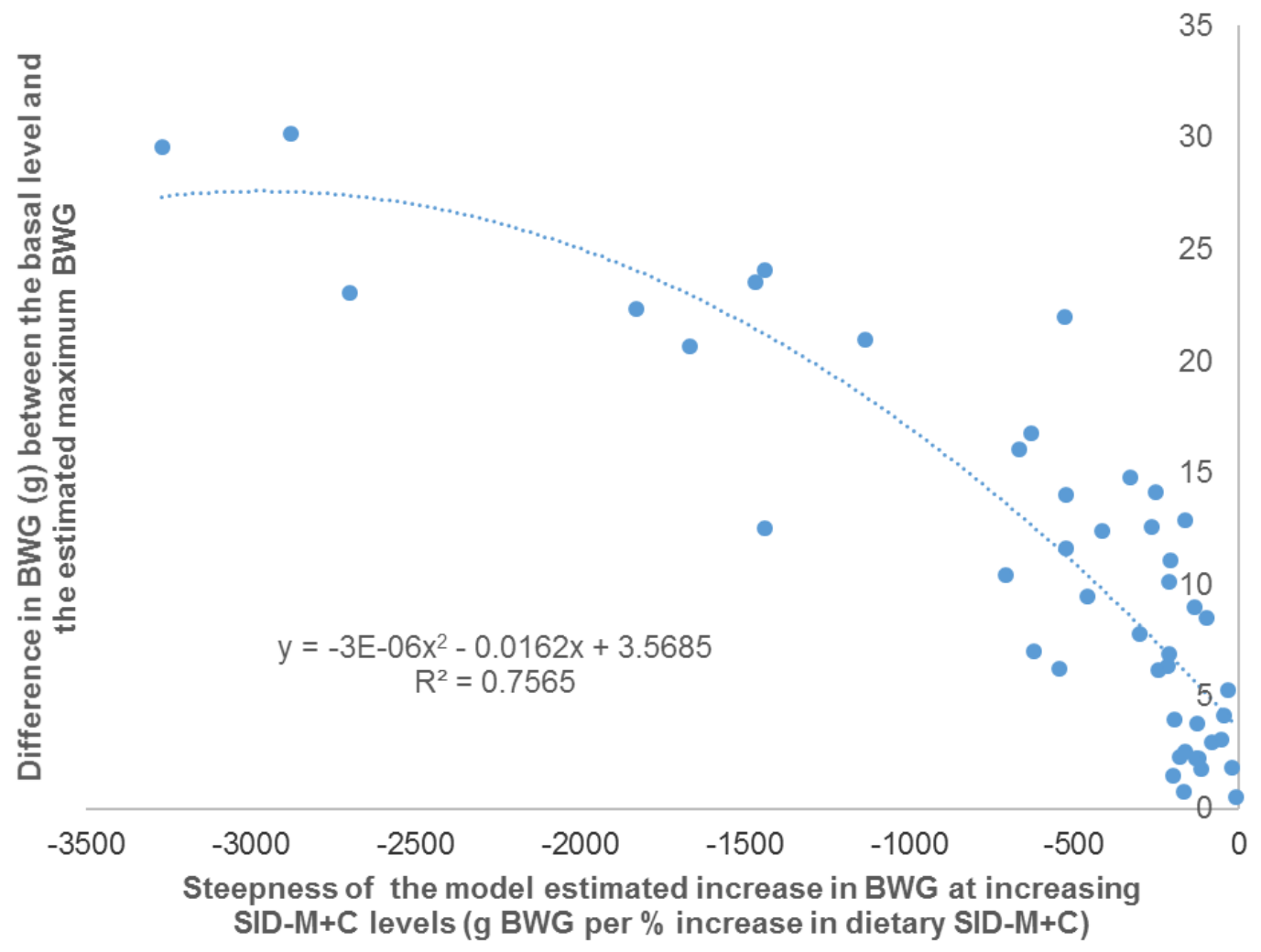

Figure 2. Relationship between the difference in BWG (g) between the basal diet and the estimated maximum BWG and the modelled steepness of the increase in BWG at increasing dietary SID-M+C levels ( $g$ BWG per percent increase in dietary SID-M+C). 


\section{Conclusions}

Based on the results of this study it is concluded that it is most prudent to base the dietary SID-M+C:LYS ratio recommendation on the complete dataset of SID-M+C trials and correct for a (random) study effect. This results in the following SID-M+C:LYS requirements:

SID-M+C:LYS for BWG $=73 \%$

SID-M+C:LYS for FCR $=74 \%$ 


\section{List of studies included in the meta-analysis}

Agostini, P. S., P. Dalibard, Y. Mercier, P. Van Der Aar, and J. D. Van Der Klis. 2016. Comparison of methionine sources around requirement levels using a methionine efficacy method in 0 to 28 day old broilers. Poultry Science 95(3):560-569.

Albino, L. F. T., S. H. M. Da Silva, J. G. Vargas Jr, H. S. Rostagno, and M. De Almeida E Silva. 1999. Methionine + Cystine Levels for Broilers from 1 to 21 and from 22 to 42 Days of Age. Revista Brasileira de Zootecnia 28(3):519-525.

Baker, D. H., S. R. Fernandez, D. M. Webel, and C. M. Parsons. 1996. Sulfur amino acid requirement and cystine replacement value of broiler chicks during the period three to six weeks posthatching. Poultry Science 75(6):737-742.

Chamruspollert, M., G. M. Pesti, and R. I. Bakalli. 2002. Determination of the methionine requirement of male and female broiler chicks using an indirect amino acid oxidation method. Poultry Science 81(7):1004-1013.

Chamruspollert, M., G. M. Pesti, and R. I. Bakalli. 2004. Influence of temperature on the arginine and methionine requirements of young broiler chicks. Journal of Applied Poultry Research 13(4):628-638.

Dozier lii, W. A. and Y. Mercier. 2013. Ratio of digestible total sulfur amino acids to lysine of broiler chicks from 1 to 15 days of age. Journal of Applied Poultry Research 22(4):862-871.

Fatufe, A. A. and M. Rodehutscord. 2005. Growth, body composition, and marginal efficiency of methionine utilization are affected by nonessential amino acid nitrogen supplementation in male broiler chicken. Poultry Science 84(10):1584-1592.

Goulart, C. D. C., F. G. P. Costa, J. H. V. da Silva, J. G. de Souza, V. P. Rodrigues, and C. F. S. de Oliveira. 2011. Requirements of digestible methionine + cystine for broiler chickens at 1 to 42 days of age. Revista Brasileira de Zootecnia 40(4):797-803.

Kalinowski, A., E. T. Moran Jr, and C. L. Wyatt. 2003. Methionine and cystine requirements of slow- and fast-feathering broiler males from three to six weeks of age. Poultry Science 82(9):1428-1437.

Lumpkins, B. S., A. B. Batal, and D. H. Baker. 2007. Variations in the digestible sulfur amino acid requirement of broiler chickens due to sex, growth criteria, rearing environment, and processing yield characteristics. Poultry Science 86(2):325-330.

Mack, S., D. Bercovici, G. De Groote, B. Leclercq, M. Lippens, M. Pack, J. B. Schutte, and S. Van Cauwenberghe. 1999. Ideal amino acid profile and dietary lysine specification for broiler chickens of 20 to 40 days of age. British Poultry Science 40(2):257-265.

Mendonca, C. X. and L. S. Jensen. 1989. Influence of protein concentration on the sulphurcontaining amino acid requirement of broiler chickens. British Poultry Science 30(4):889-898.

Rakangtong, C. and C. Bunchasak. 2011. Effect of total sulfur amino acids in corn-cassavasoybean diets on growth performance, carcass yield and blood chemical profile of male broiler chickens from 1 to 42 days of age. Animal Production Science 51(3):198-203.

Shen, Y. B., P. Ferket, I. Park, R. D. Malheiros, and S. W. Kim. 2015. Effects of feed grade L-methionine on intestinal redox status, intestinal development, and growth performance of young chickens compared with conventional DL-methionine. Journal of Animal Science 93(6):2977-2986.

Zelenka, J., J. Heger, V. Machander, M. Wiltafsky, and M. Lešták. 2013. Bioavailability of liquid methionine hydroxy analogue-free acid relative to DL-methionine in broilers. Acta Universitatis Agriculturae et Silviculturae Mendelianae Brunensis 61(5):15131520. 


\section{References}

Blok and Dekker. 2017. Table 'Standardized ileal digestibility of amino acids in feedstuffs for poultry'. CVB Documentation report nr. 61.

Spek, J.W. 2018. Standardized ileal digestible lysine requirement for broilers. CVB Documentation report n. 62.

Veldkamp, T., J.W. van Riel, R.A. Dekker, S. Khalaji, V. Khaksar, H. Hashemipour, M.M. van Krimpen, and M.C. Blok. 2016. Estimating requirement values for apparent faecal digestible and standardised ileal digestible methionine+cysteine in broilers by a meta-analysis approach. 


\section{Appendix A. Relationship between dietary SID-M+C supply and performance parameters FCR and BWG for the various titration trials.}

On the $x$-axis of the Figures the dietary $M+C$ concentration (\%) is given and on the $y$-axis of the Figures the FCR (left hand Figures) and BWG (right hand figures) are given. The closed circles are the observed values and the 'c' symbols are the fitted values.

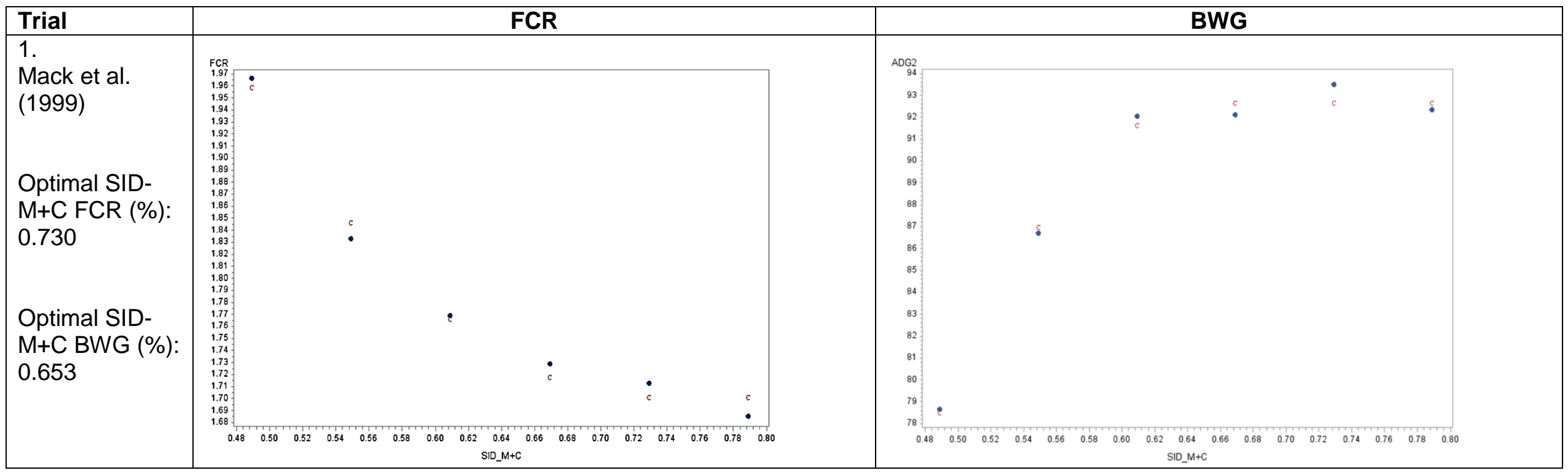




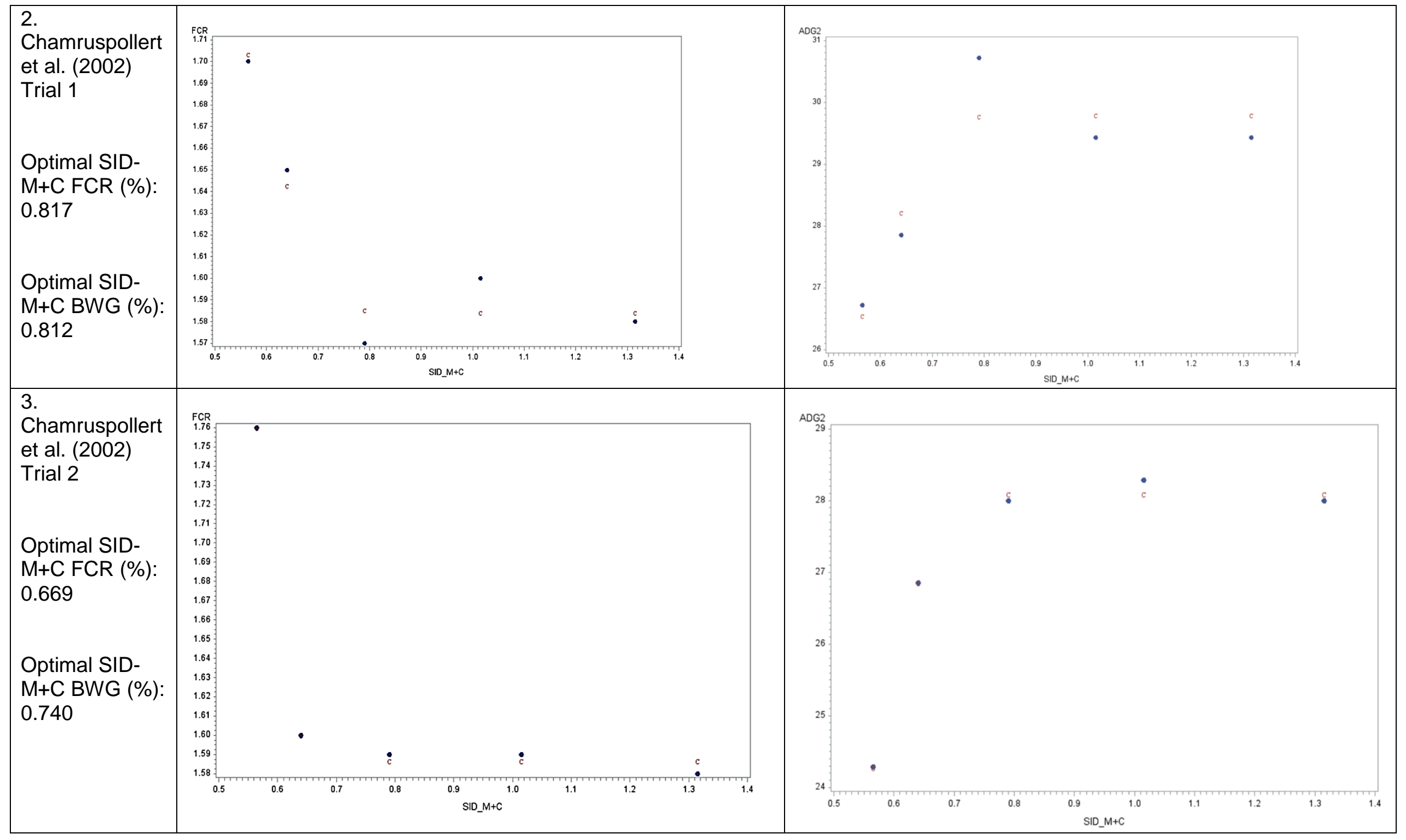




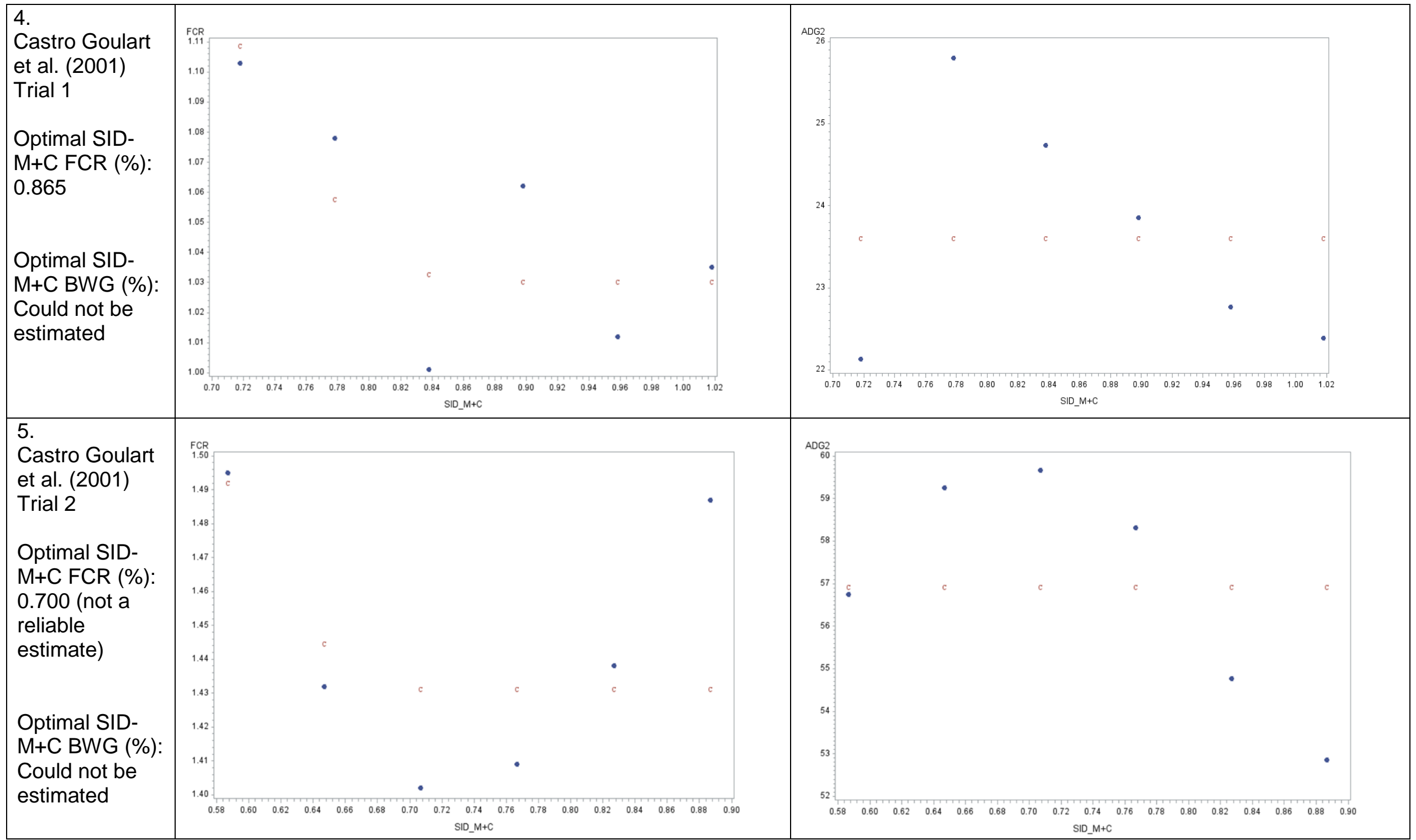




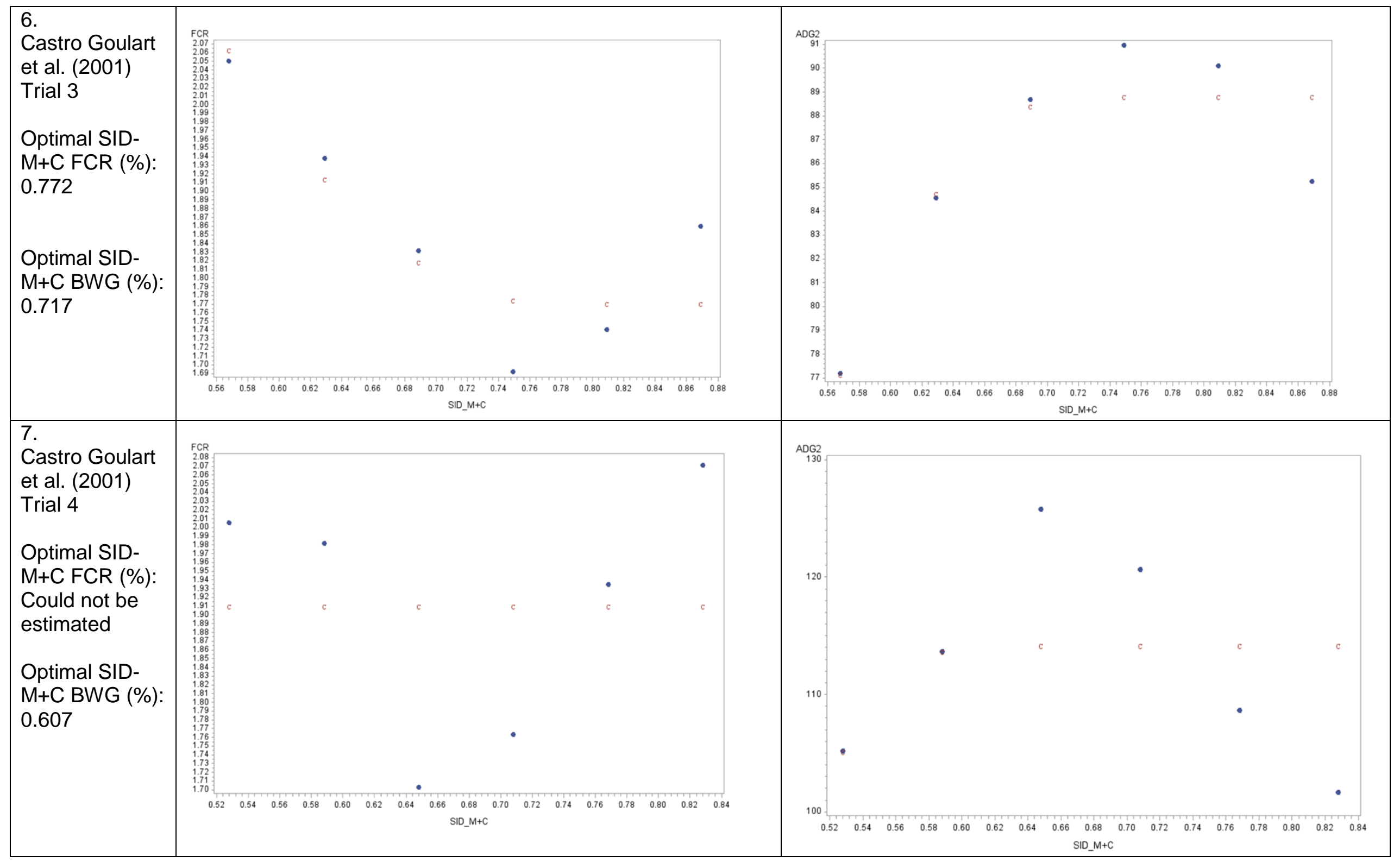




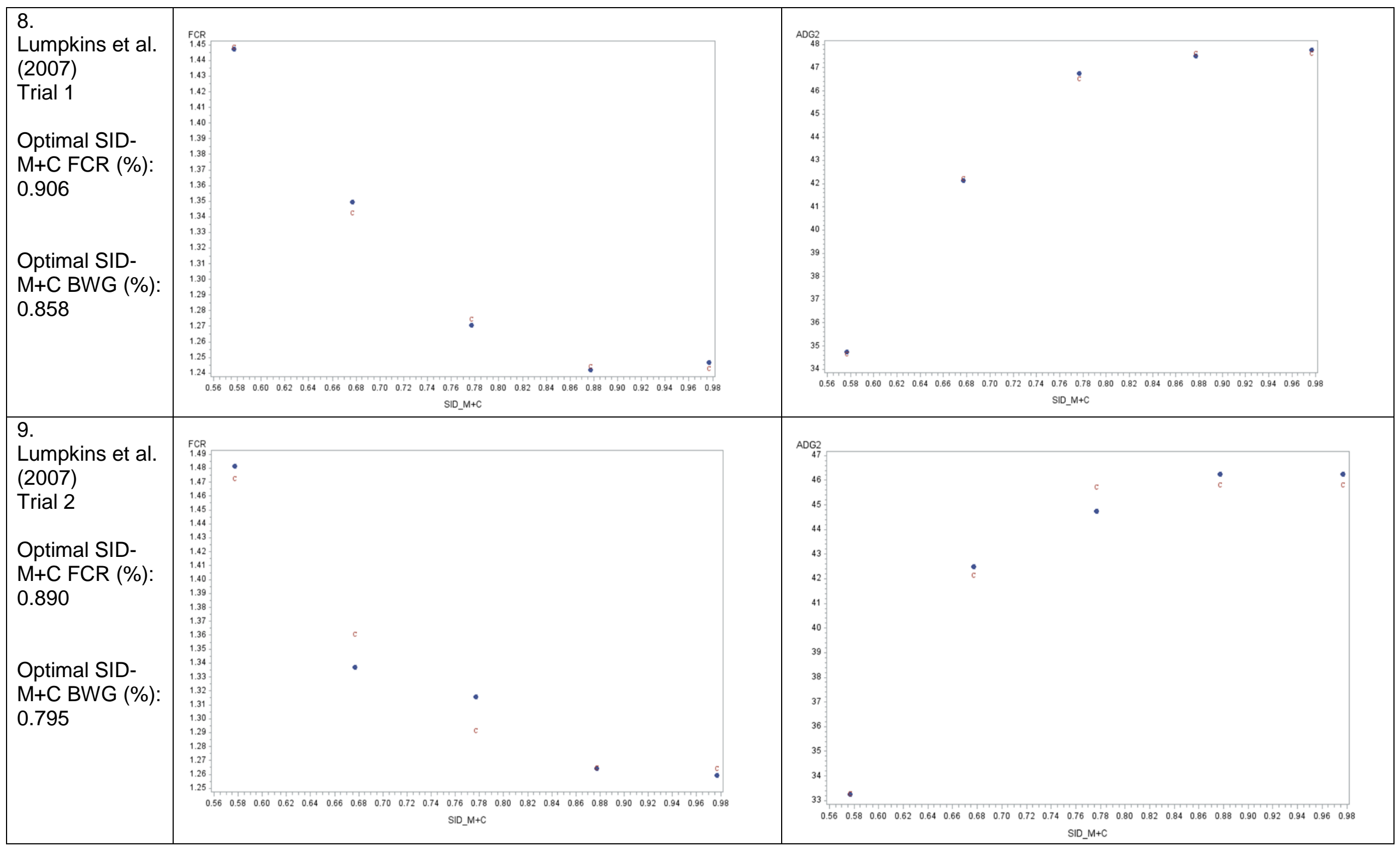




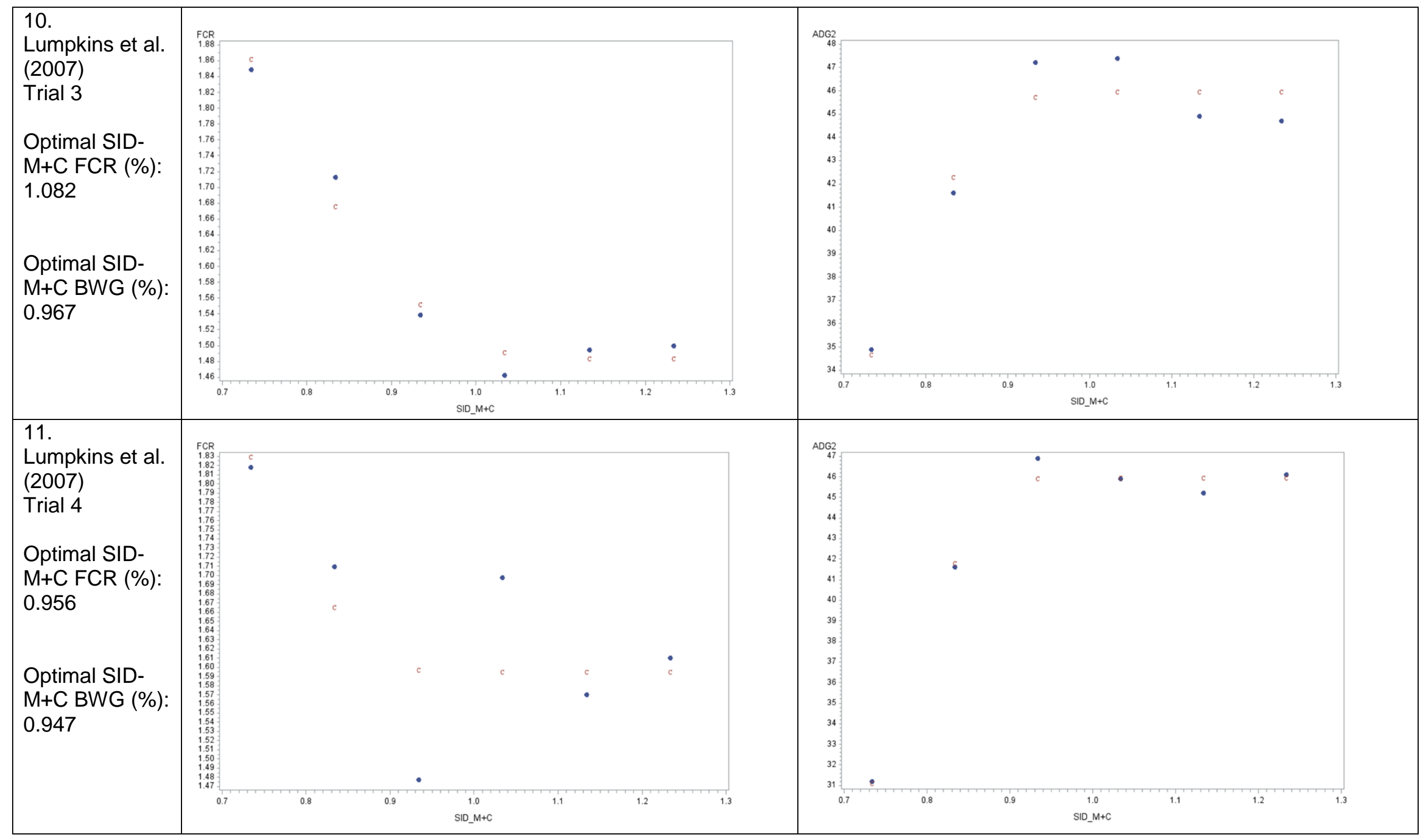




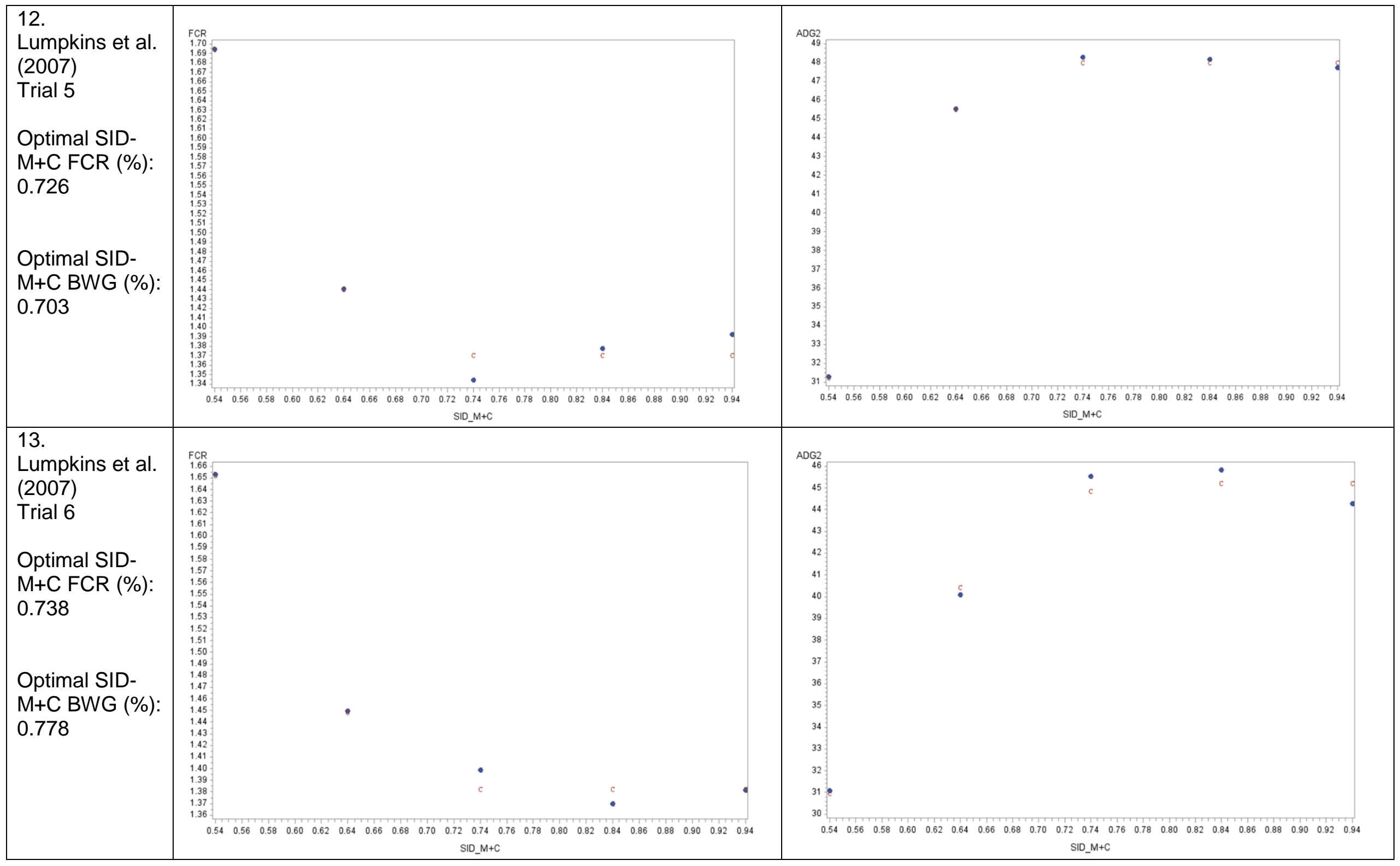




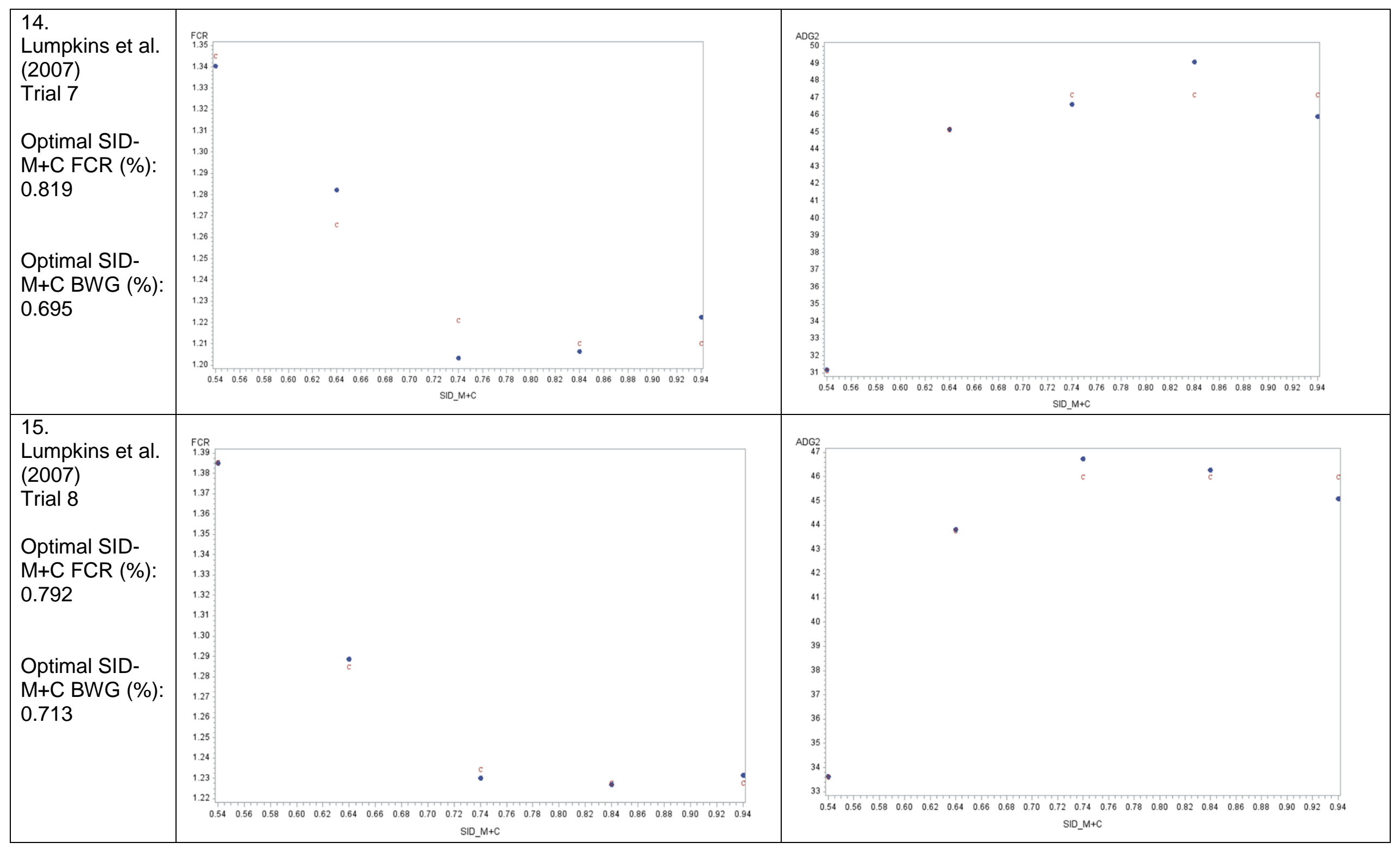




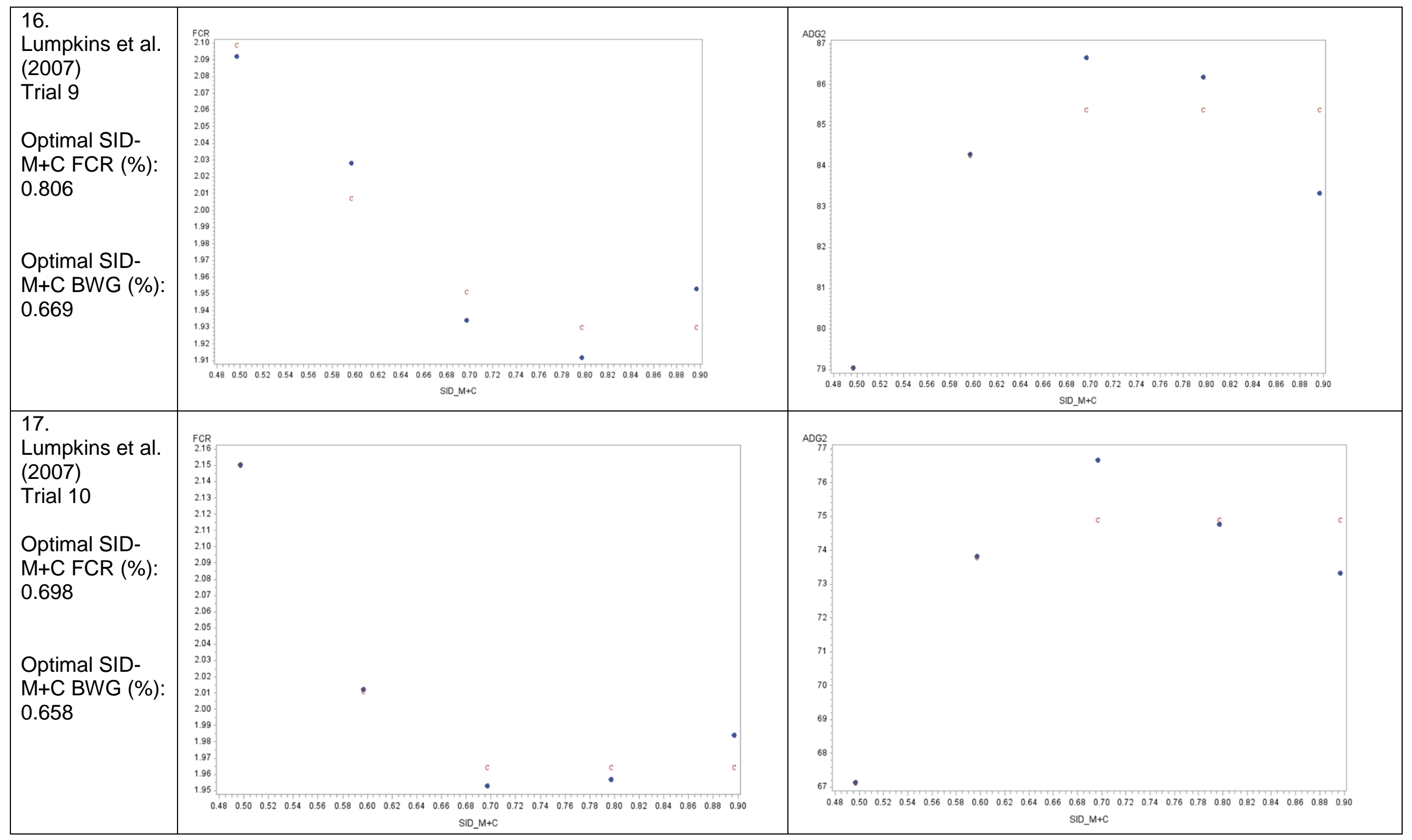




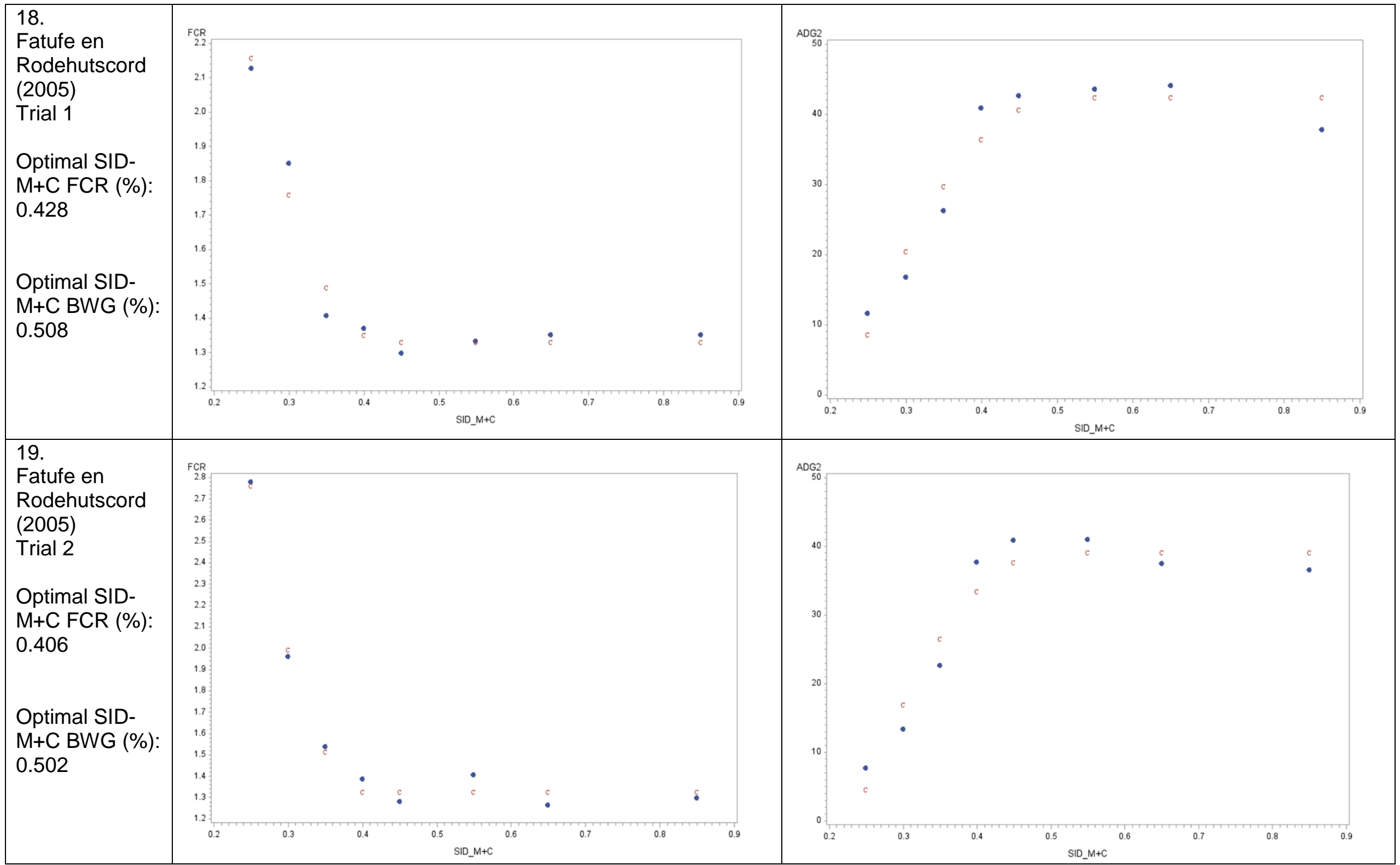




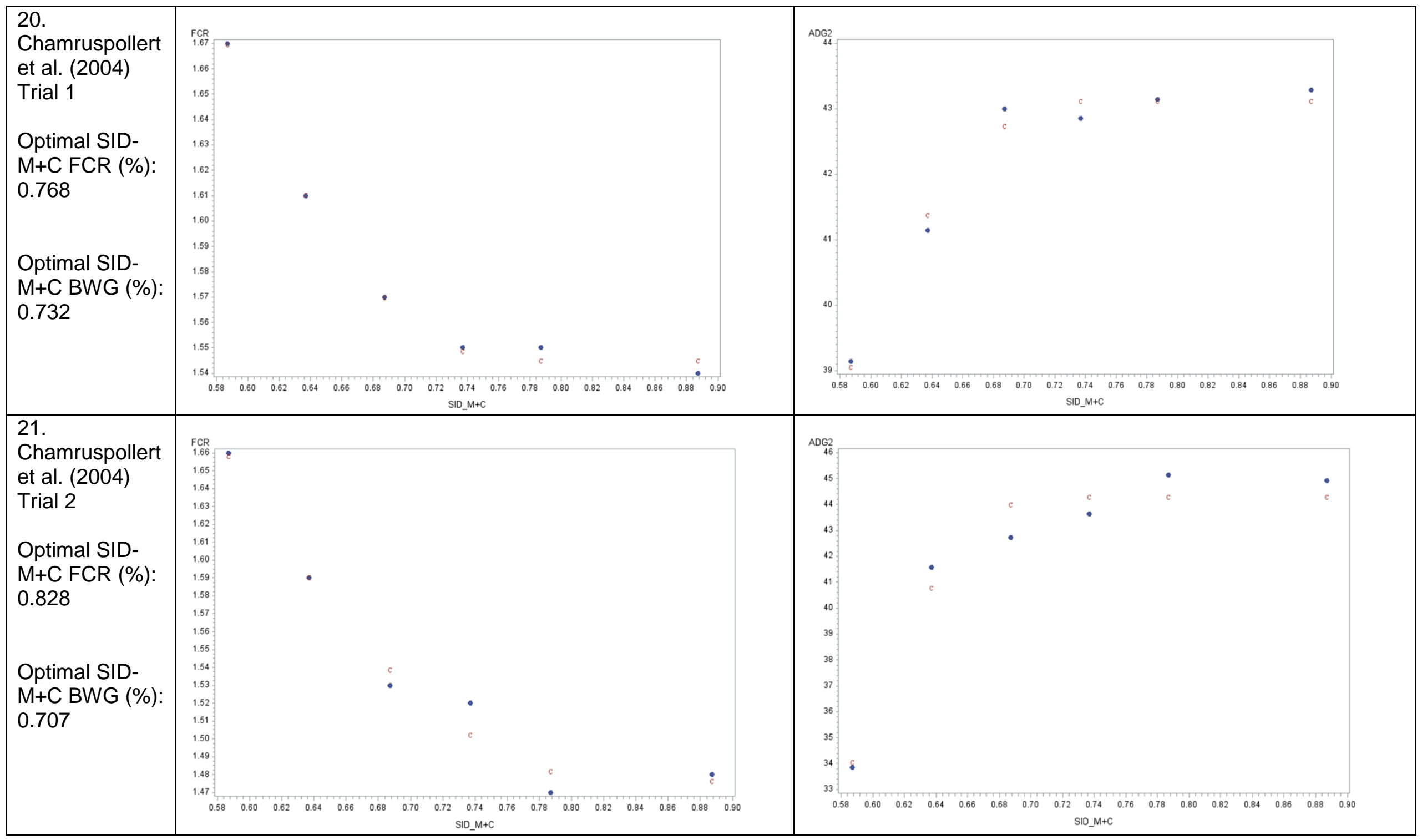




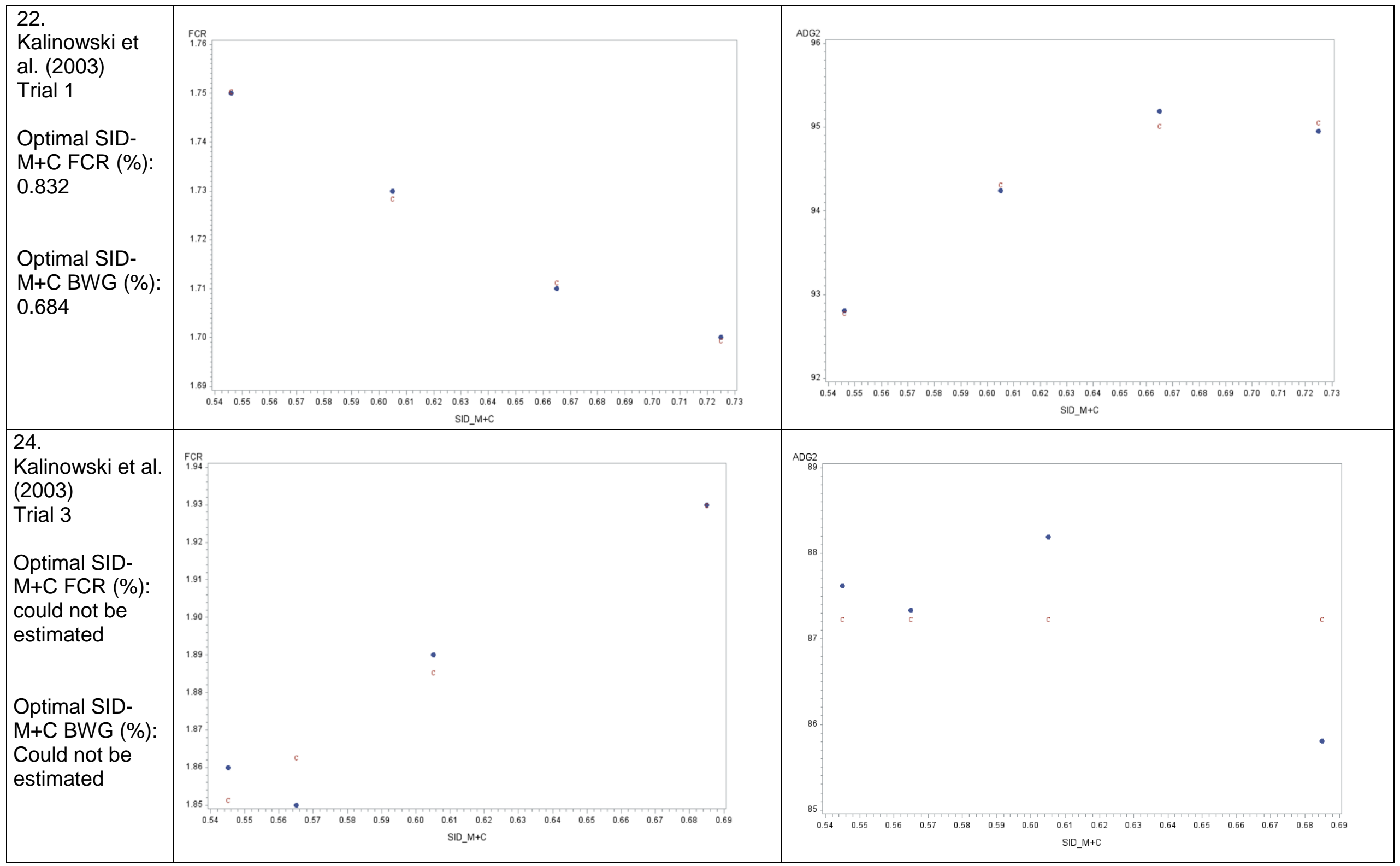




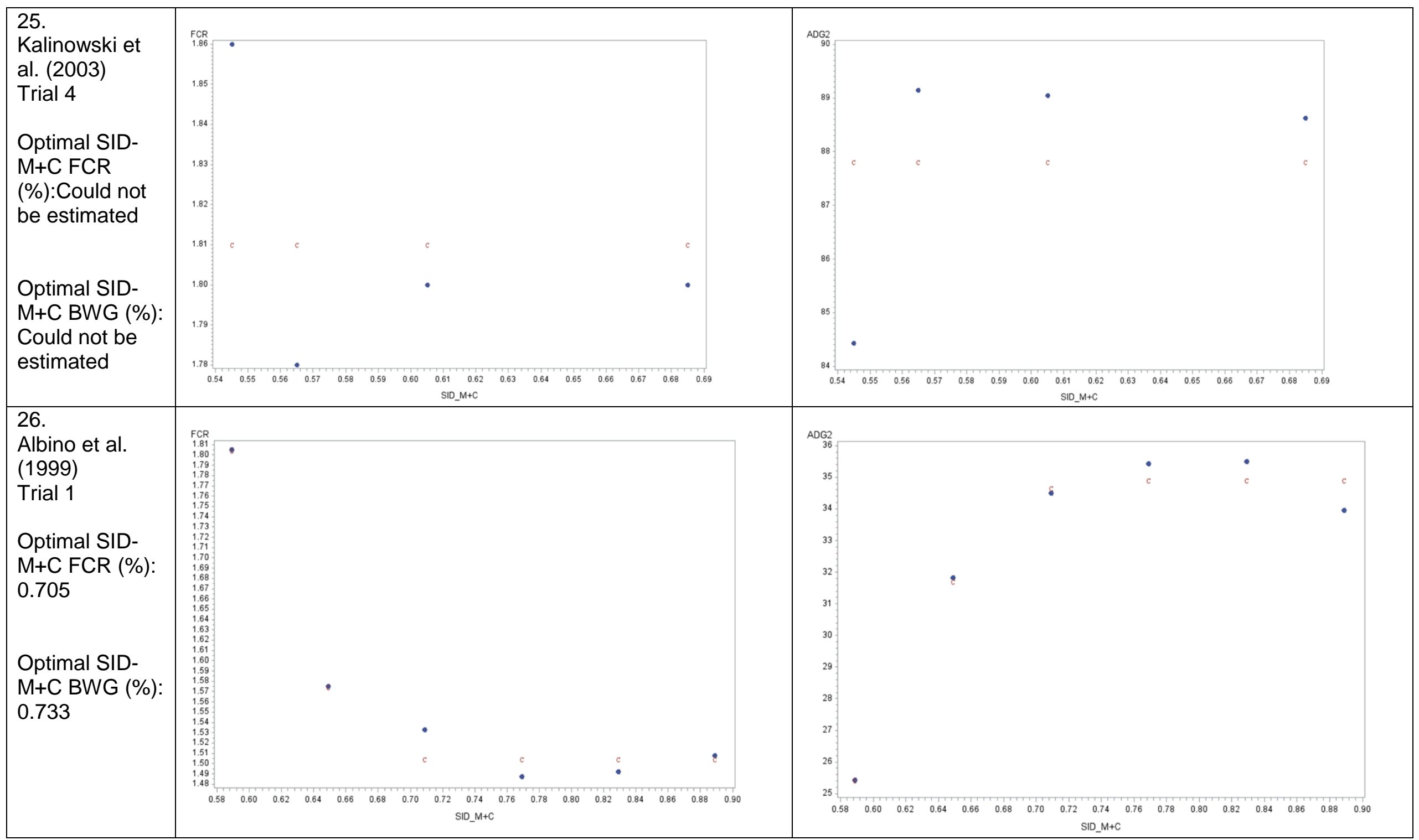




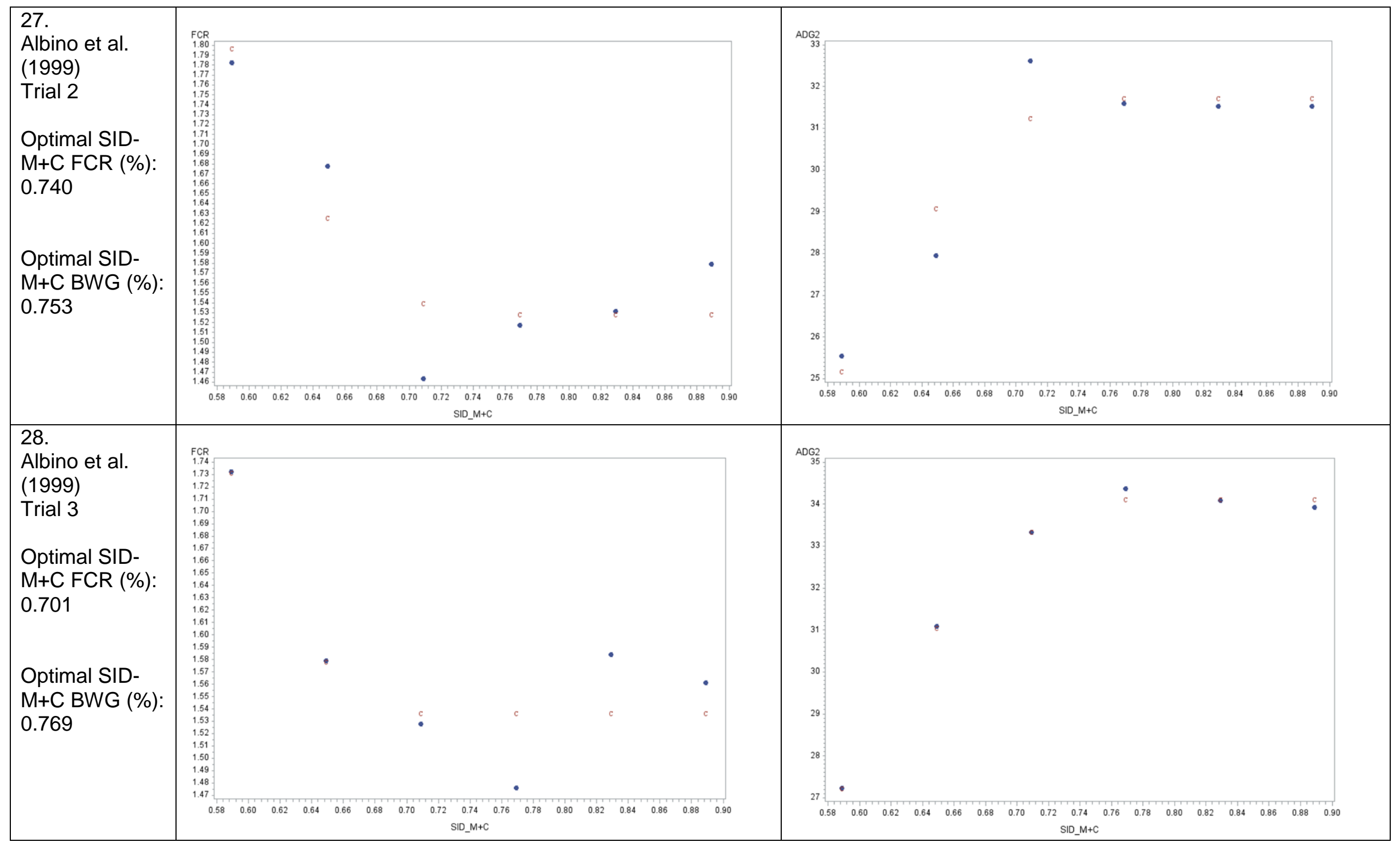




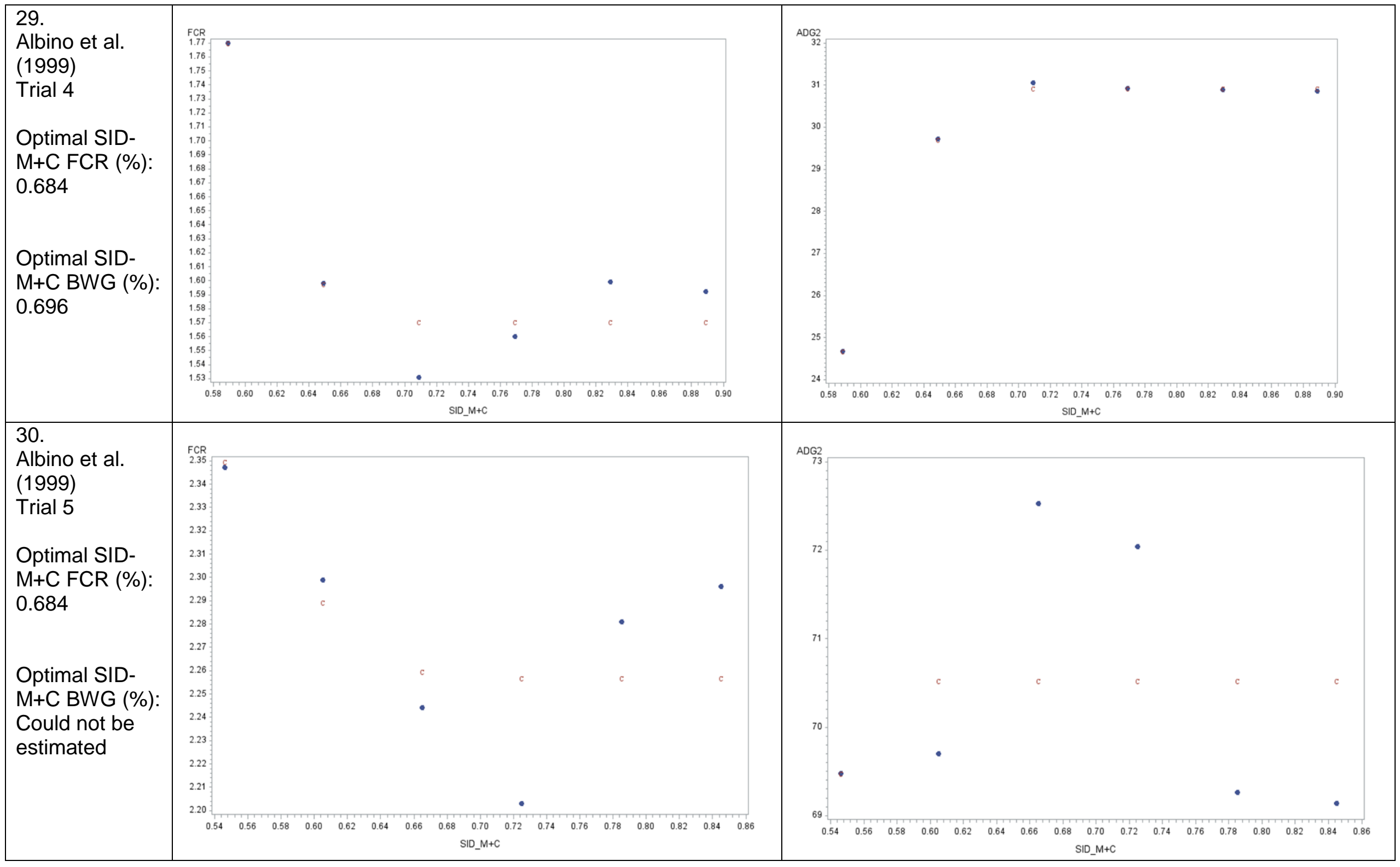




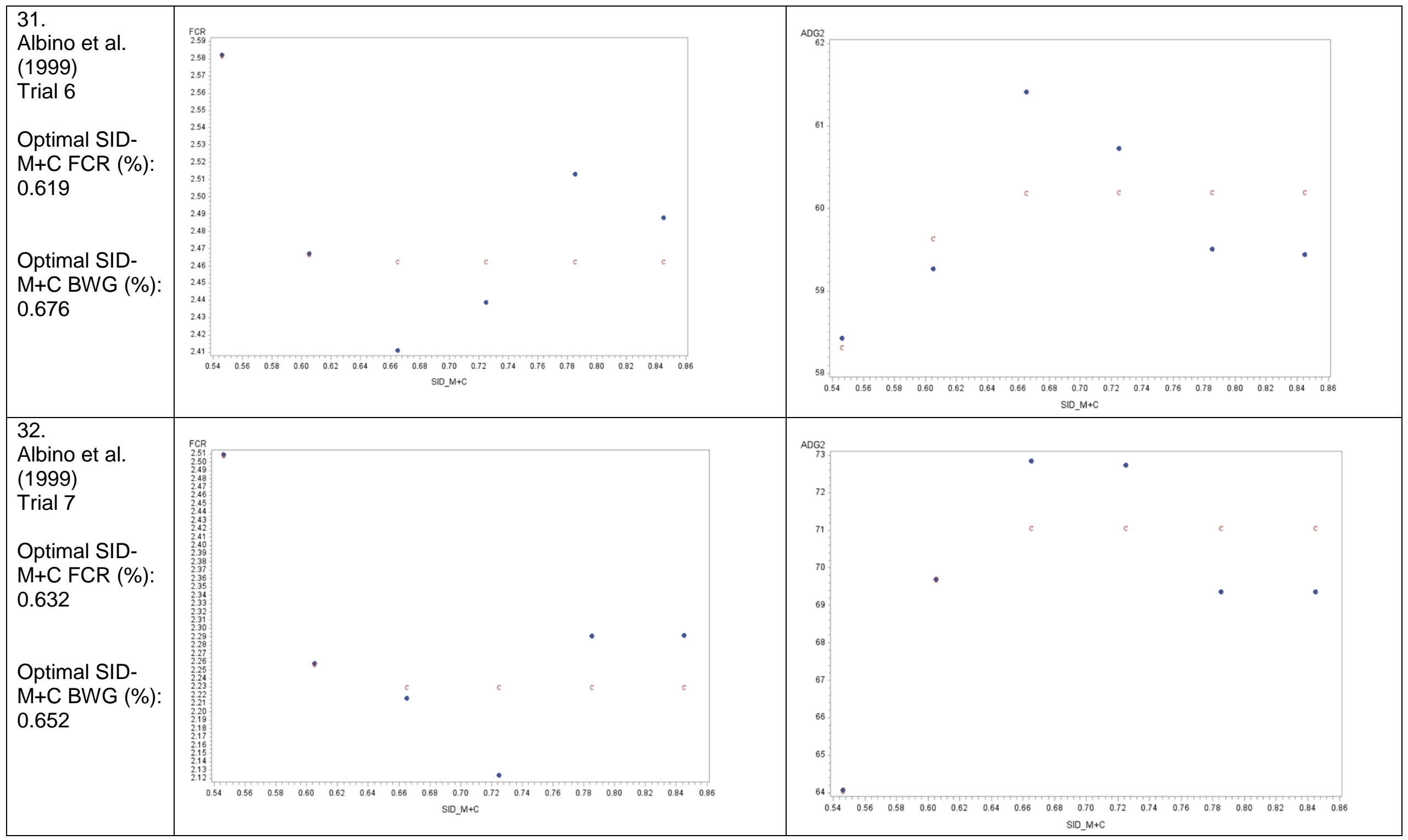




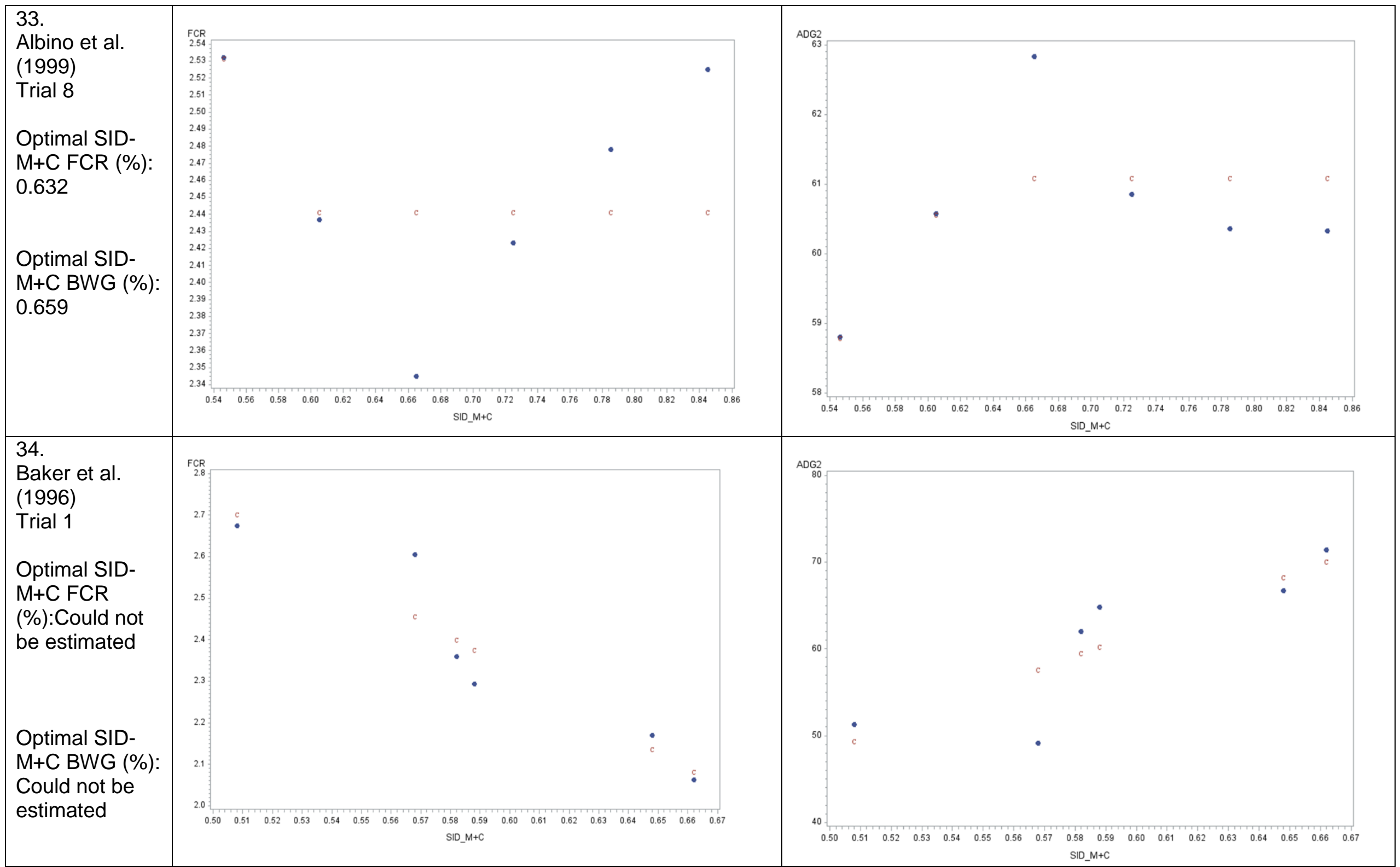




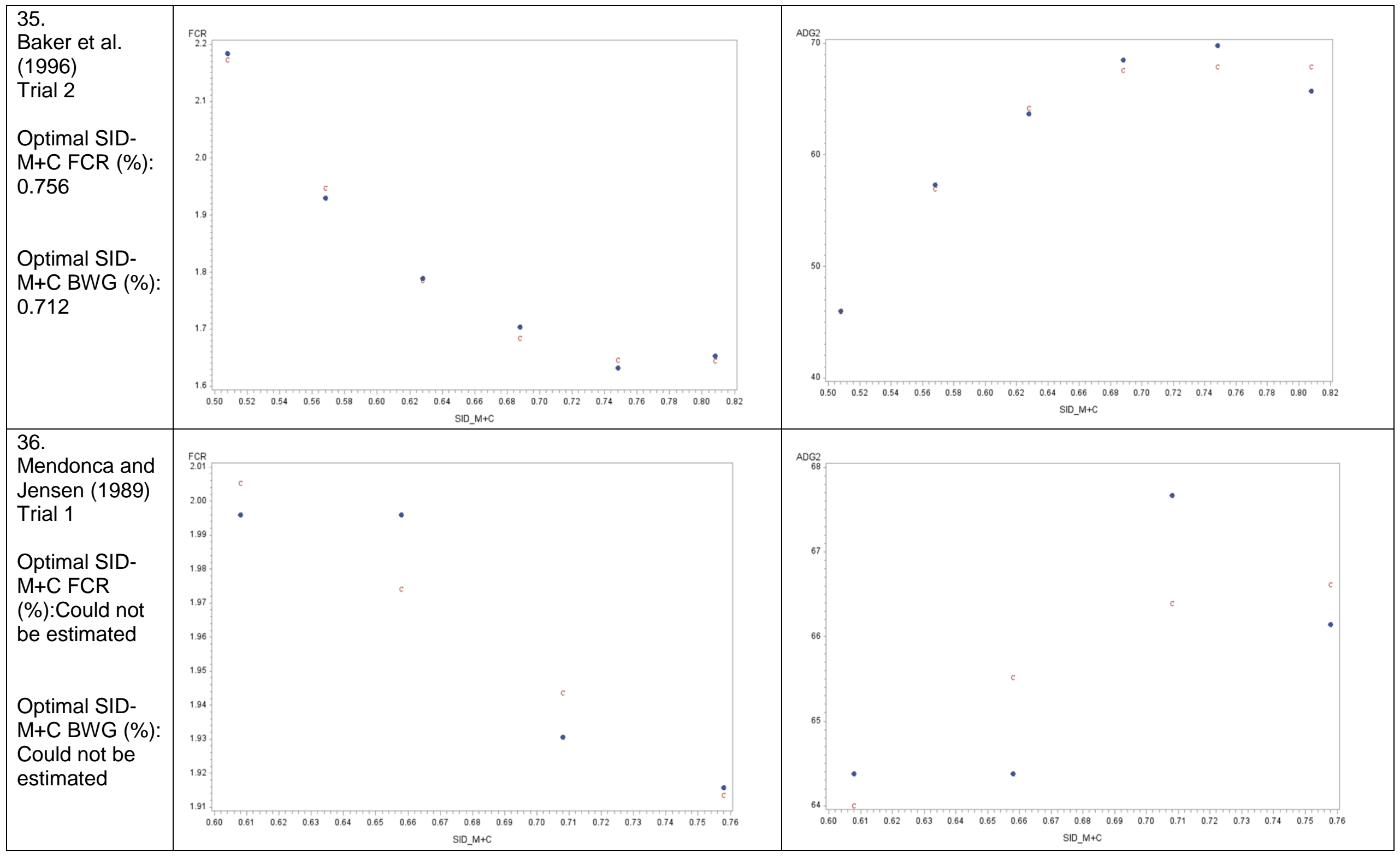




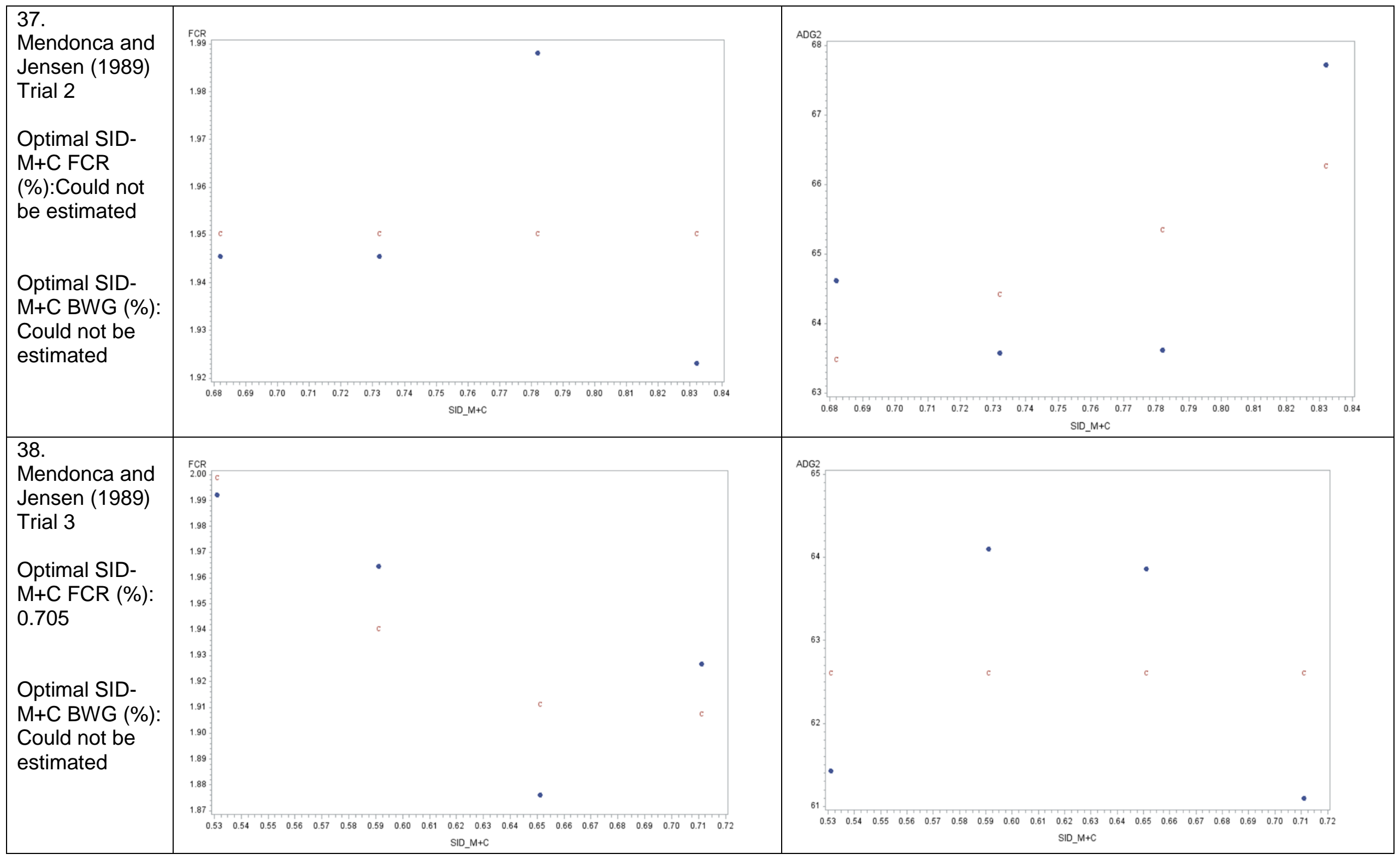




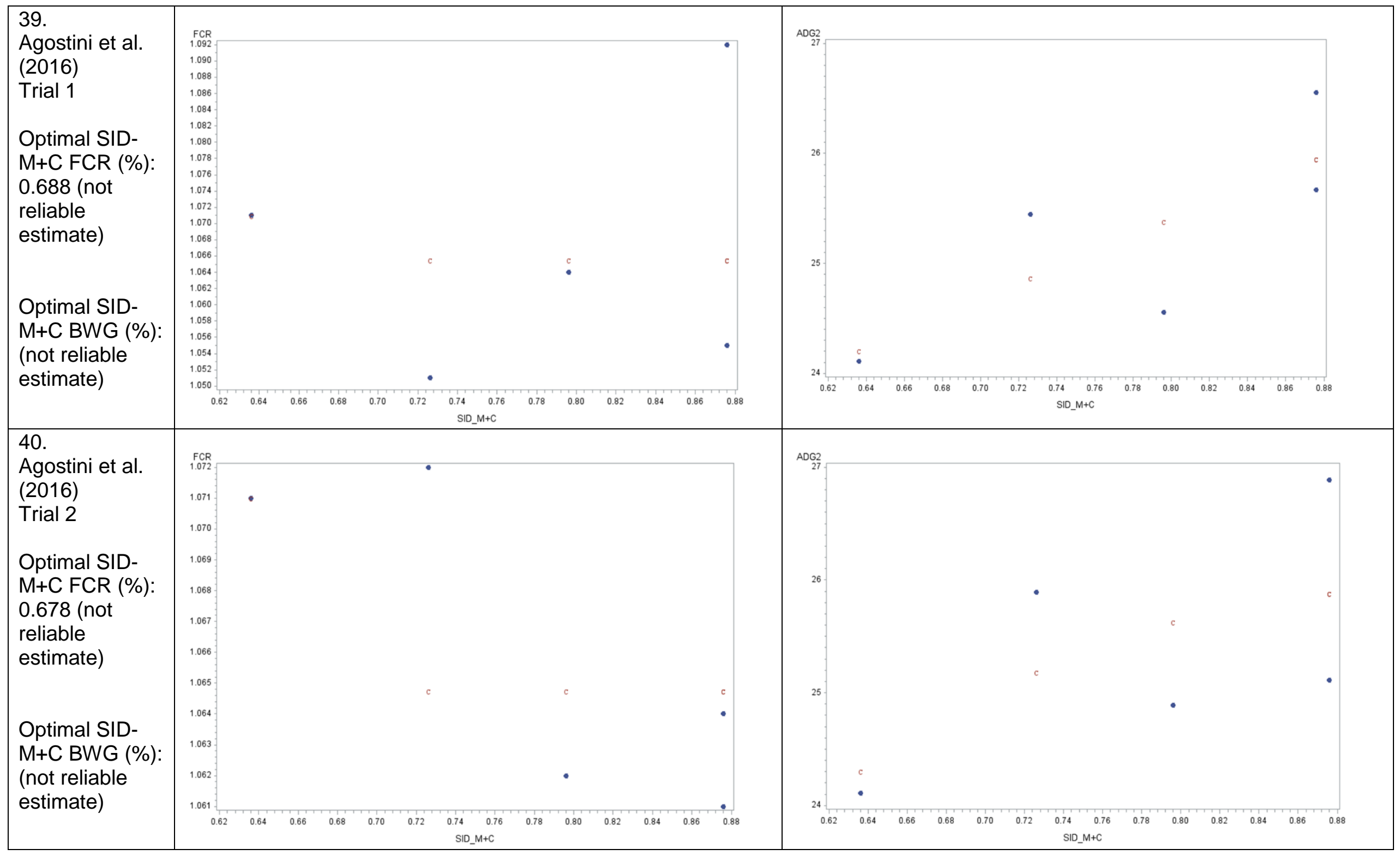

35 


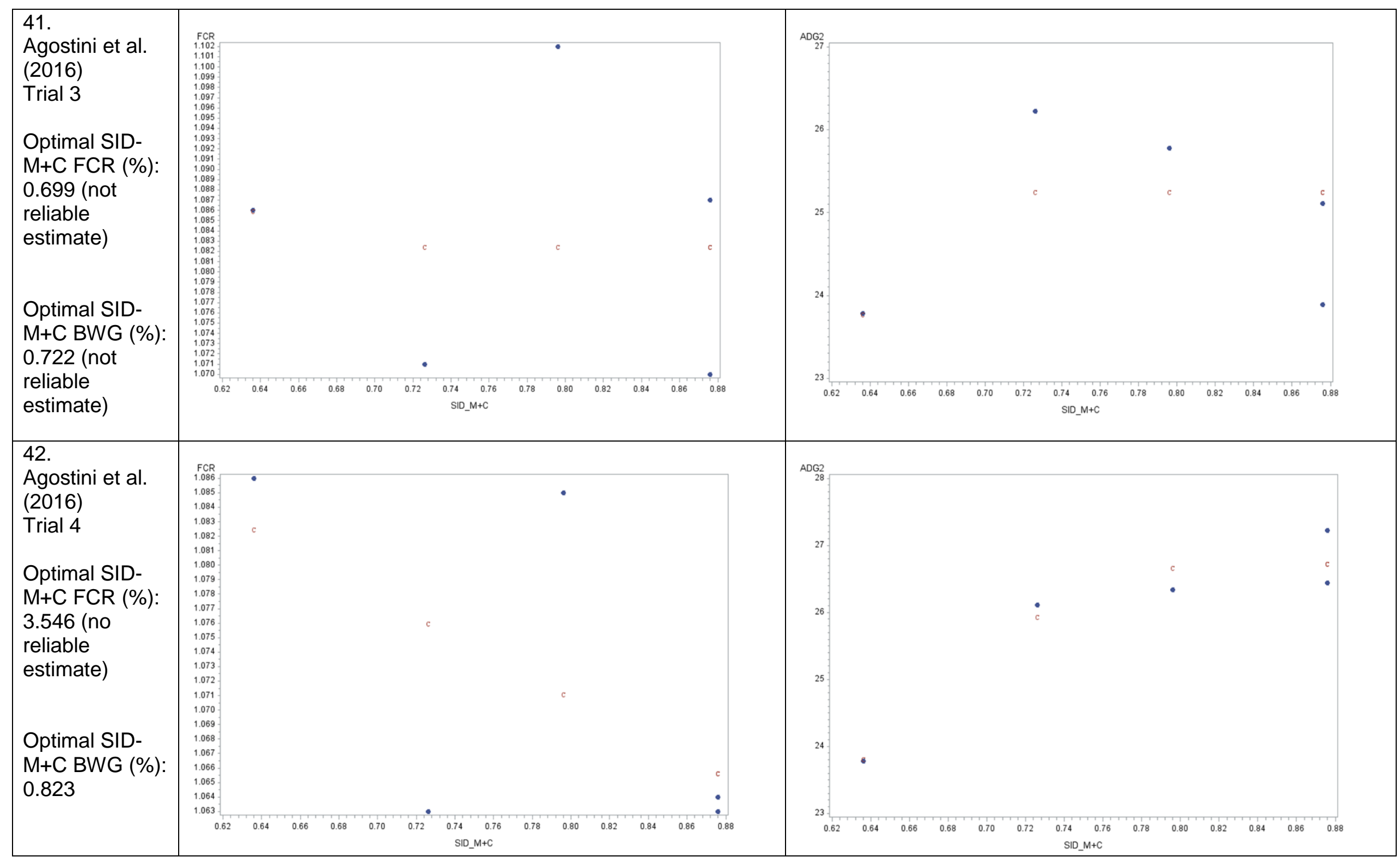




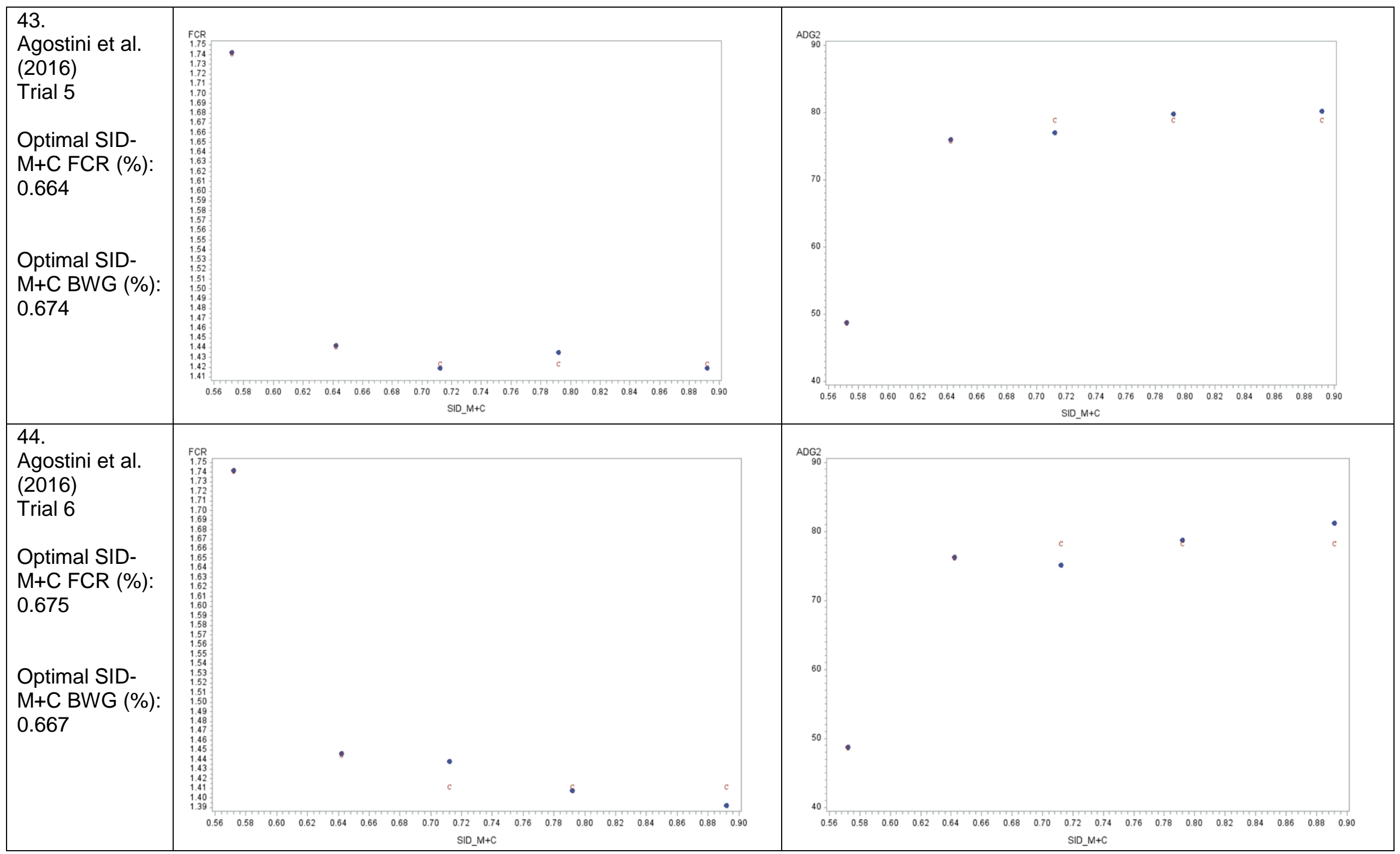




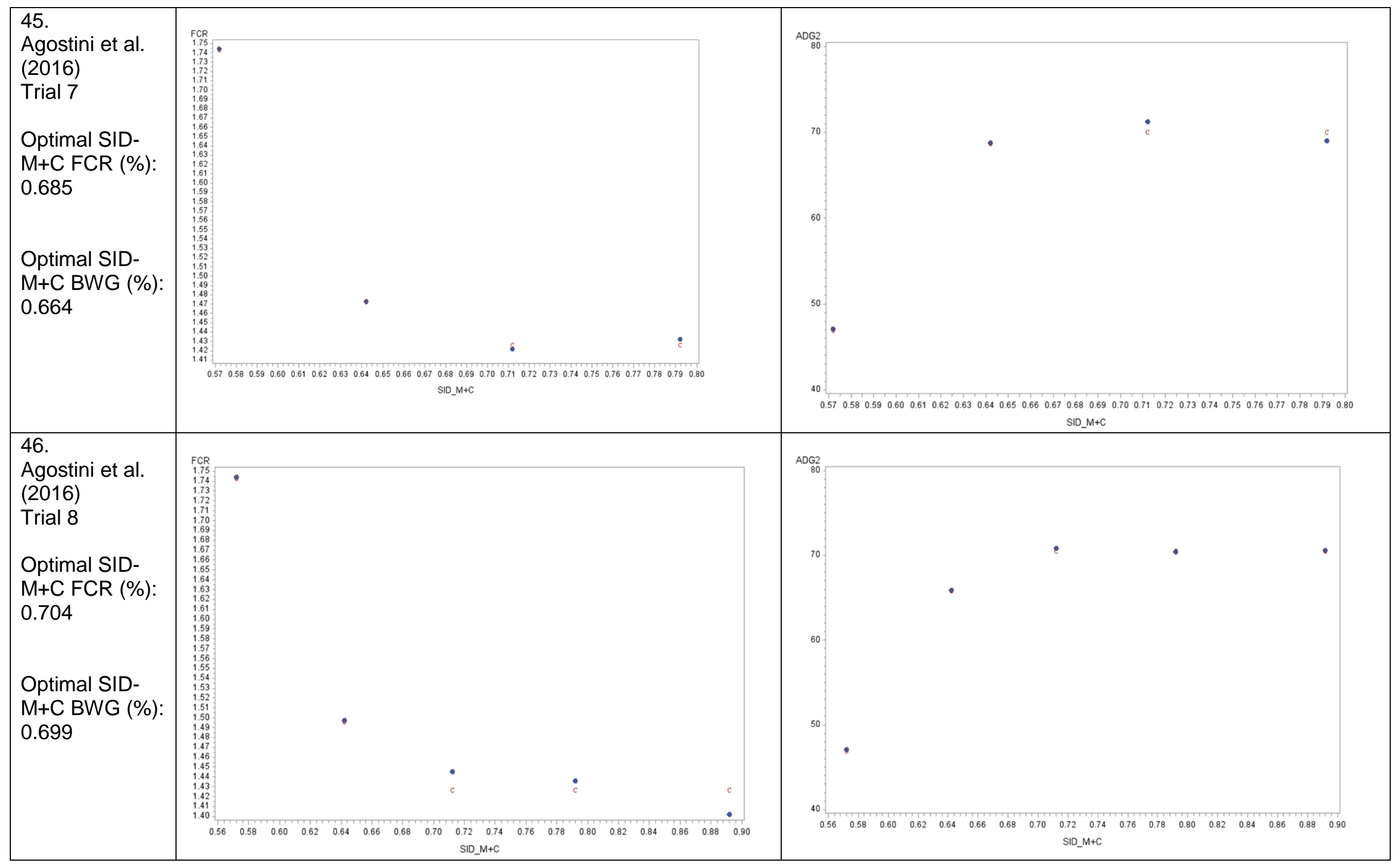




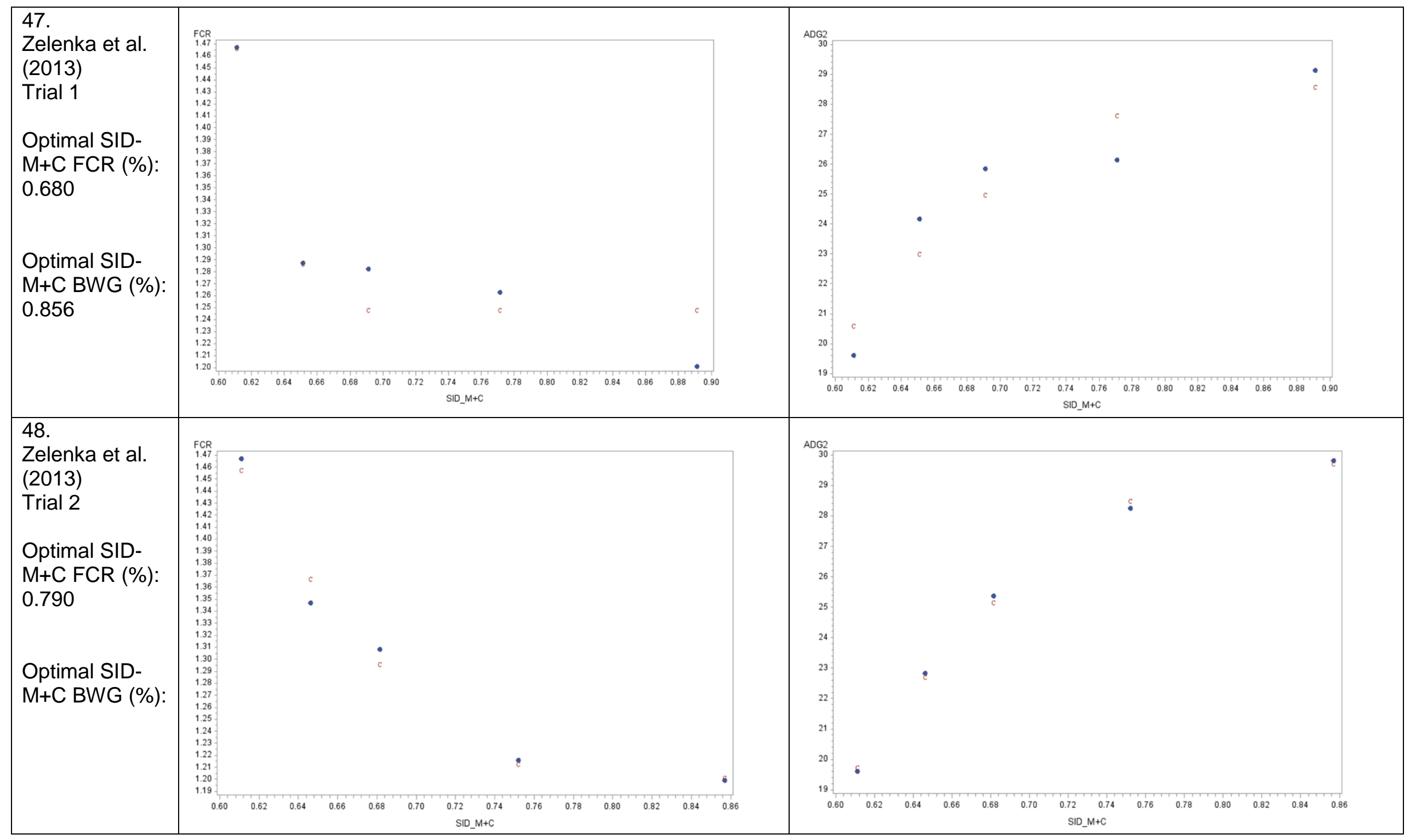




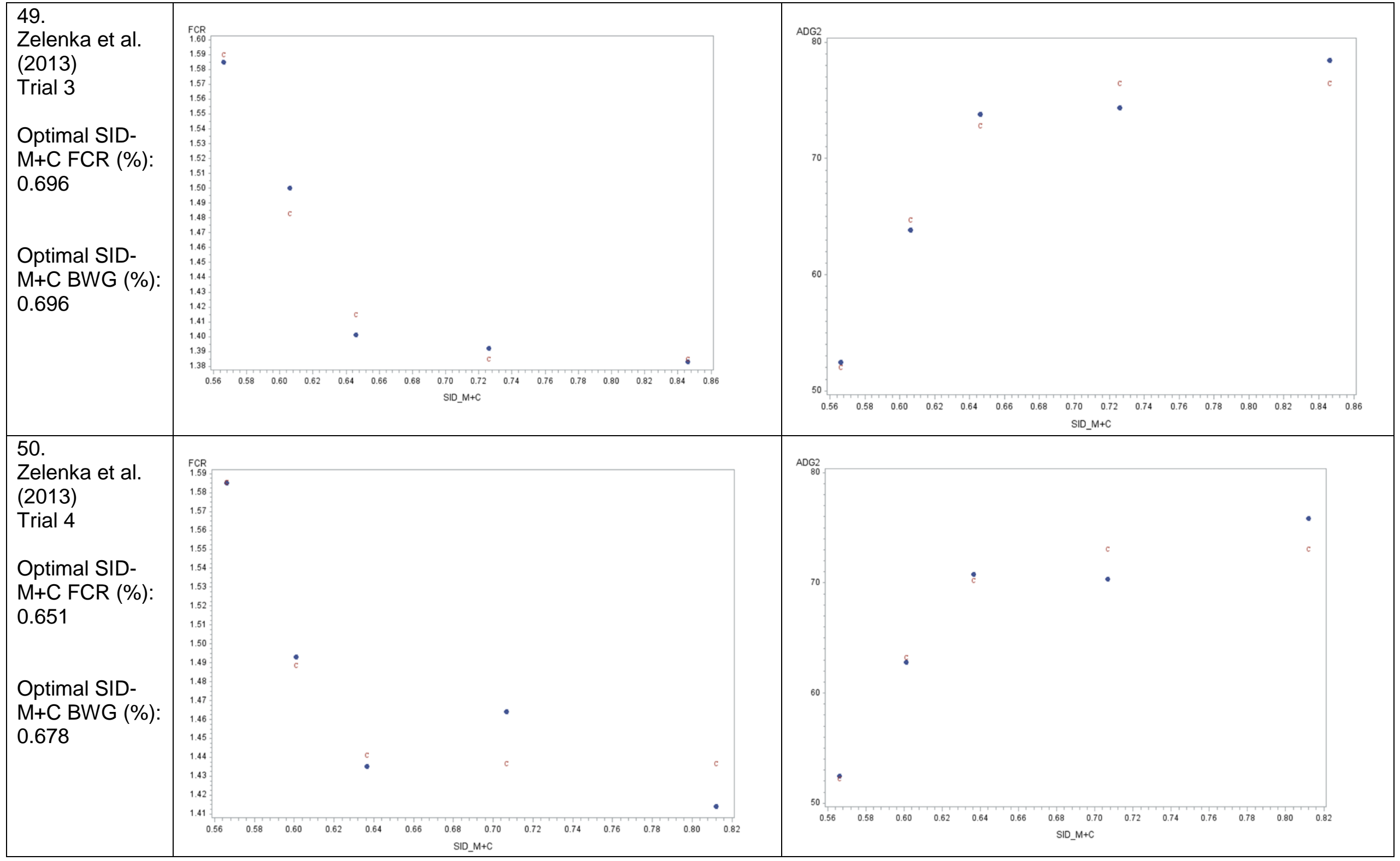




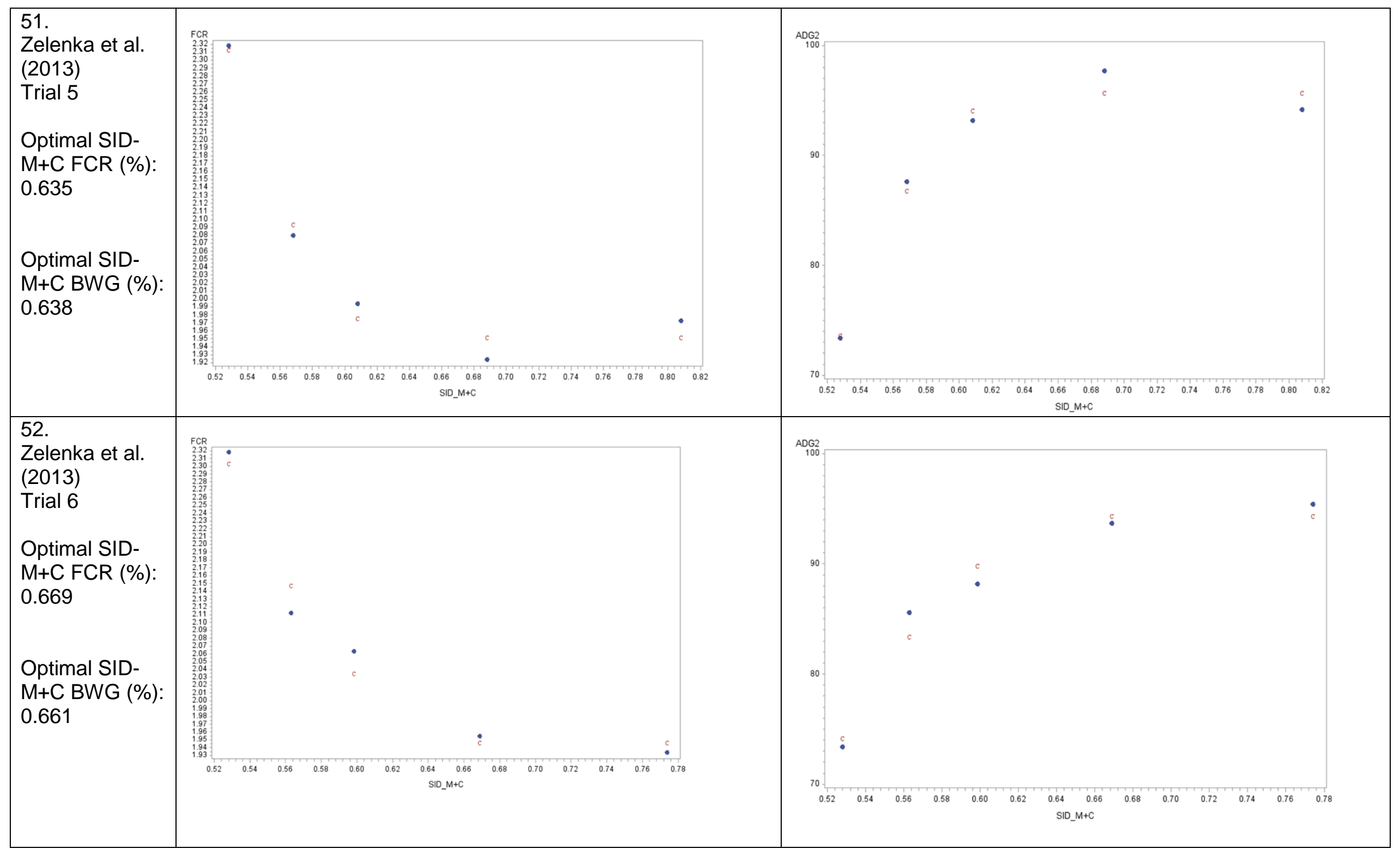




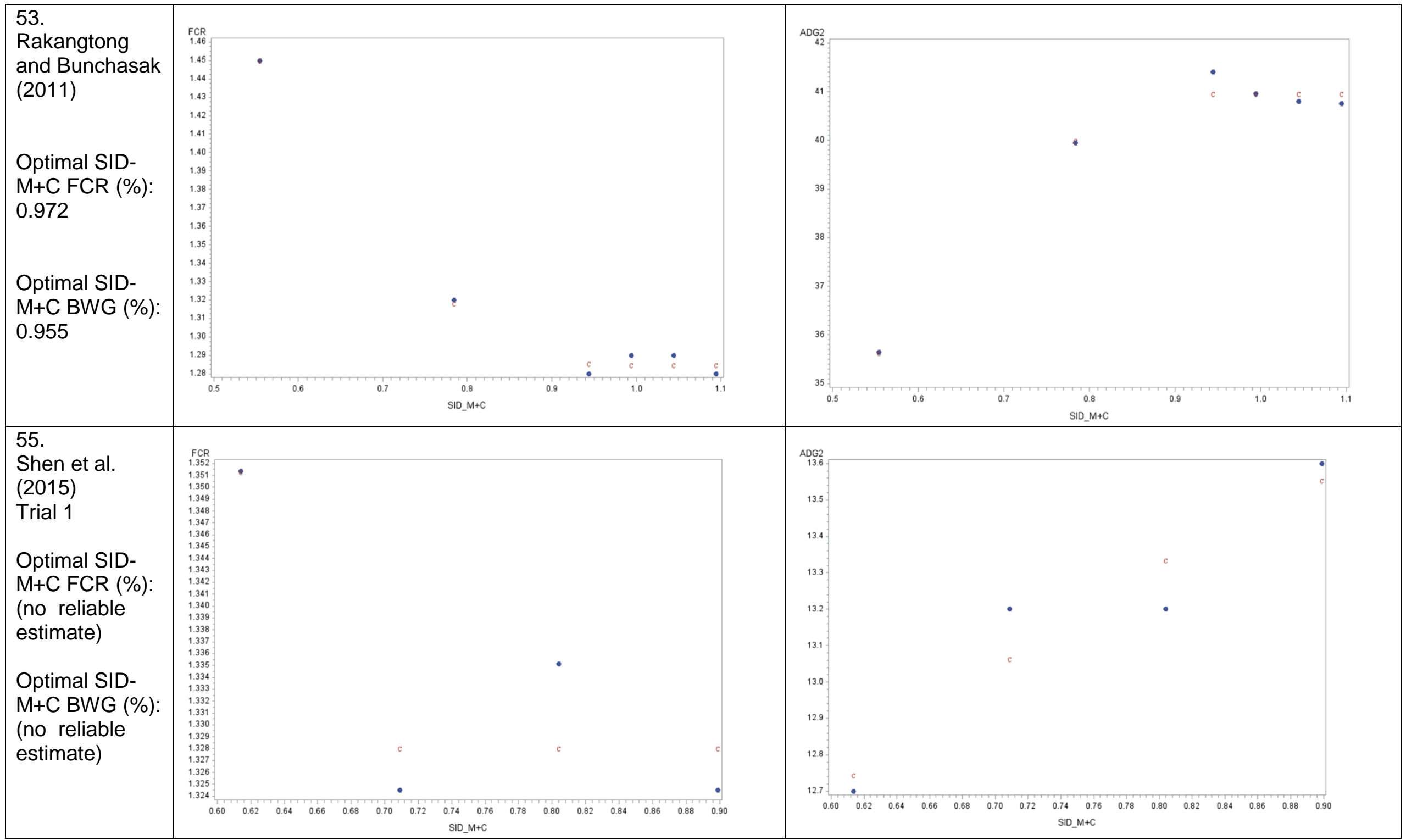




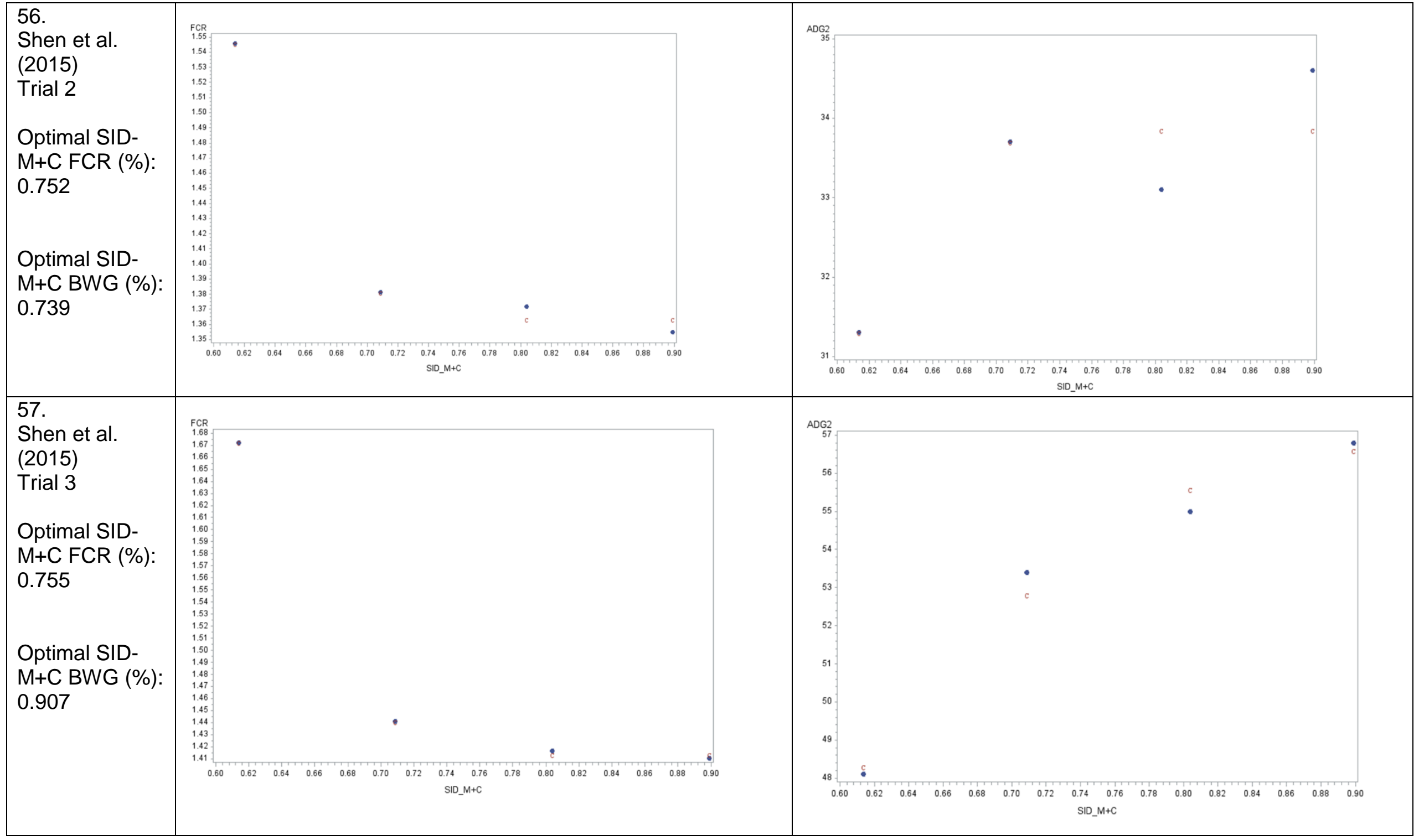




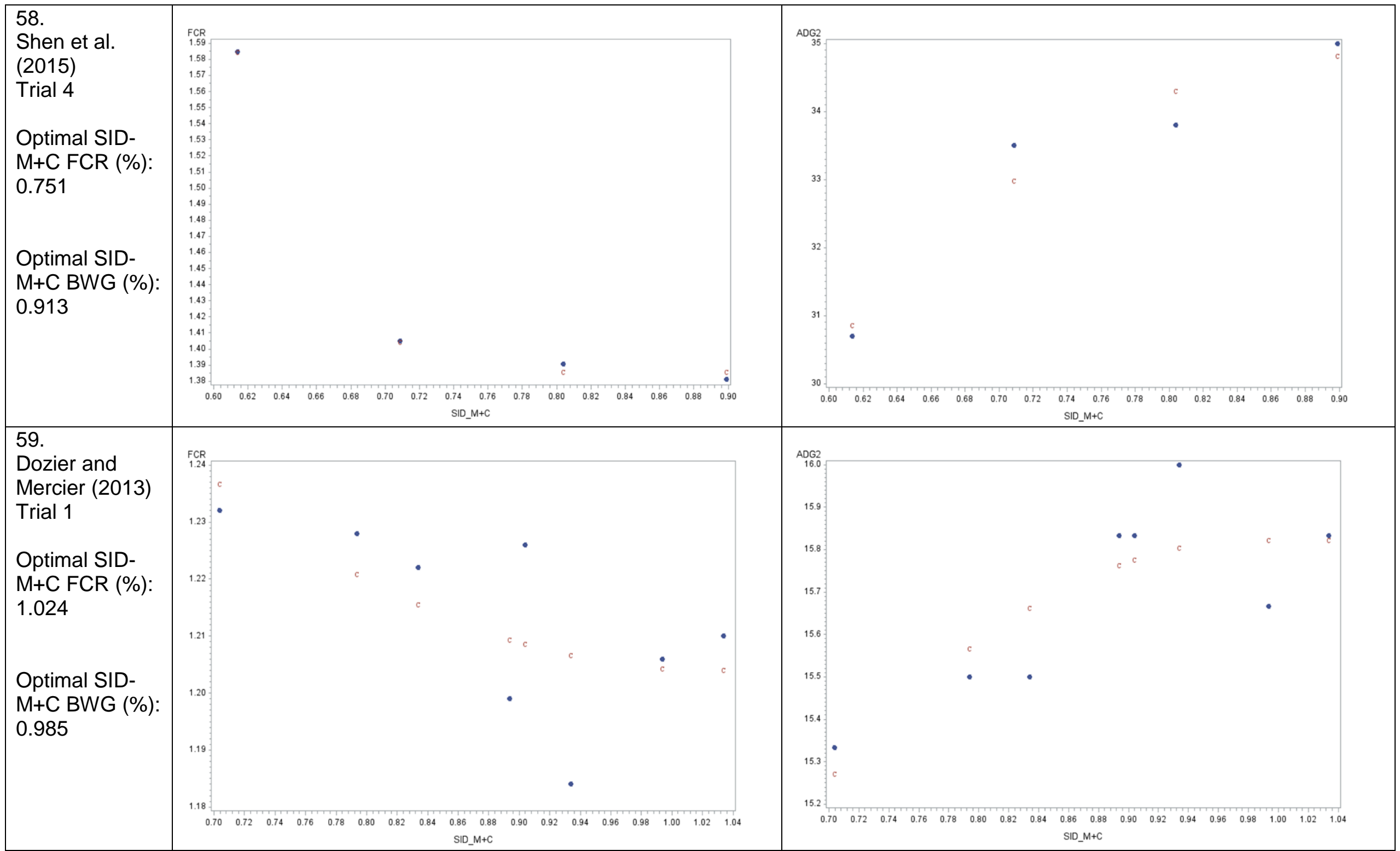




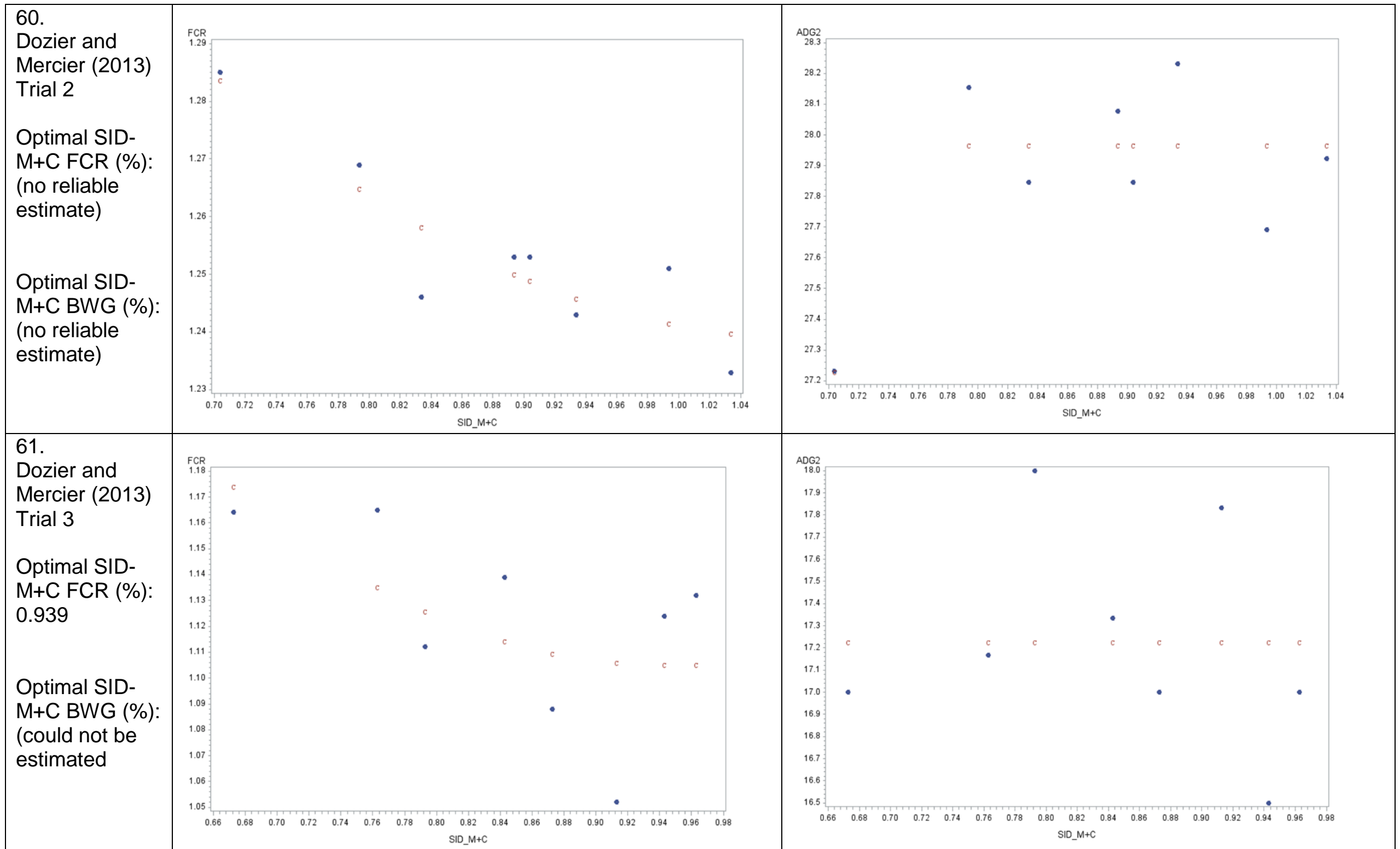




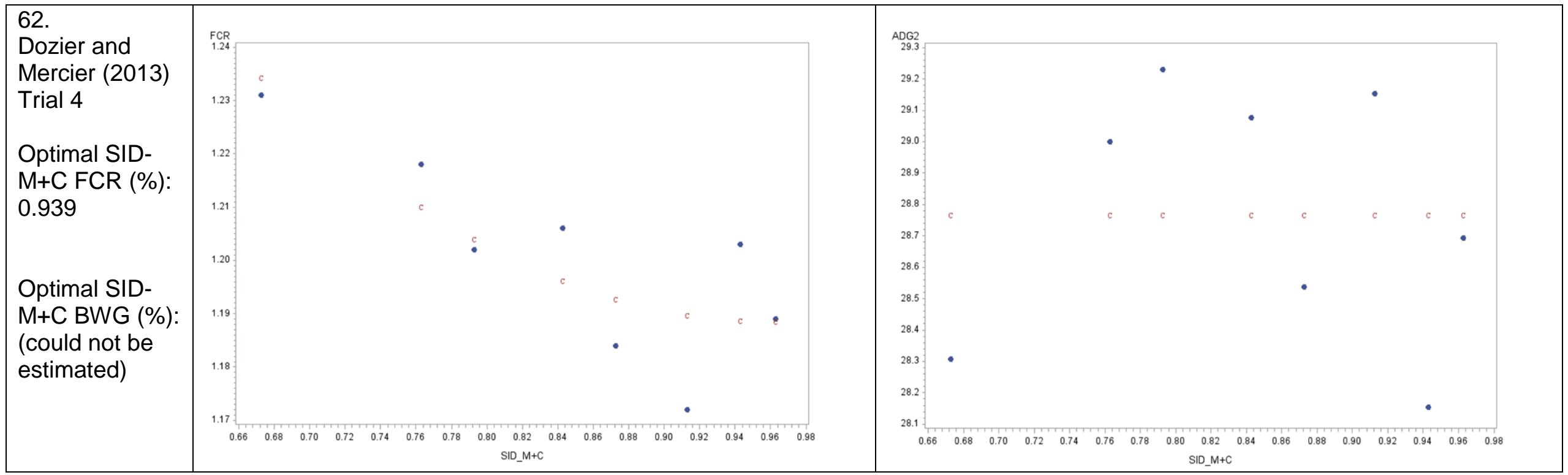




\section{Appendix B. SID-M+C model estimates using the quadratic broken-line model for minimum FCR and maximum BWG}

\begin{tabular}{|c|c|c|c|c|c|c|c|}
\hline Trial nr. & $\begin{array}{r}\text { Estimate } \\
\mathrm{L}\end{array}$ & $\begin{array}{r}\text { Std. Err. } \\
\text { L }\end{array}$ & $\begin{array}{r}\text { Estimate } \\
\mathbf{R}\end{array}$ & $\begin{array}{r}\text { Std. Err. } \\
R\end{array}$ & $\begin{array}{r}\text { Estimate } \\
\mathrm{U}\end{array}$ & $\begin{array}{r}\text { Std. } \\
\text { Err. U }\end{array}$ & $\mathbf{R}^{2}$ \\
\hline 1 & 1.702 & 0.0111 & 0.730 & 0.0291 & 4.4 & 1.09 & 0.986 \\
\hline 2 & 1.584 & 0.0108 & 0.817 & 0.0967 & 1.9 & 1.49 & 0.952 \\
\hline 3 & 1.587 & 0.0033 & 0.669 & 0.0098 & 16.1 & 2.99 & 0.998 \\
\hline 4 & 1.030 & 0.0171 & 0.865 & 0.1222 & 3.6 & 6.21 & 0.638 \\
\hline 5 & 1.432 & 0.0160 & 0.700 & 0.0000 & 4.7 & 2.98 & 0.387 \\
\hline 6 & 1.771 & 0.0474 & 0.772 & 0.1045 & 7.0 & 7.43 & 0.805 \\
\hline \multicolumn{8}{|l|}{7} \\
\hline 8 & 1.243 & 0.0052 & 0.906 & 0.0232 & 1.9 & 0.26 & 0.997 \\
\hline 9 & 1.265 & 0.0188 & 0.890 & 0.0817 & 2.1 & 1.11 & 0.961 \\
\hline 10 & 1.485 & 0.0202 & 1.082 & 0.0575 & 3.1 & 1.06 & 0.976 \\
\hline 11 & 1.596 & 0.0517 & 0.956 & 0.2037 & 4.8 & 9.05 & 0.612 \\
\hline 12 & 1.371 & 0.0144 & 0.726 & 0.0323 & 9.3 & 3.30 & 0.985 \\
\hline 13 & 1.383 & 0.0084 & 0.738 & 0.0238 & 6.9 & 1.70 & 0.992 \\
\hline 14 & 1.211 & 0.0135 & 0.819 & 0.0853 & 1.7 & 1.08 & 0.946 \\
\hline 15 & 1.228 & 0.0033 & 0.792 & 0.0170 & 2.5 & 0.34 & 0.998 \\
\hline 16 & 1.931 & 0.0210 & 0.806 & 0.1119 & 1.8 & 1.29 & 0.927 \\
\hline 17 & 1.965 & 0.0098 & 0.698 & 0.0412 & 4.6 & 1.94 & 0.978 \\
\hline 18 & 1.332 & 0.0293 & 0.428 & 0.0238 & 25.9 & 7.38 & 0.972 \\
\hline 19 & 1.328 & 0.0278 & 0.406 & 0.0124 & 58.4 & 9.96 & 0.990 \\
\hline 20 & 1.545 & 0.0028 & 0.768 & 0.0120 & 3.8 & 0.52 & 0.996 \\
\hline 21 & 1.477 & 0.0118 & 0.828 & 0.0380 & 3.1 & 0.95 & 0.979 \\
\hline 22 & 1.691 & 0.0108 & 0.832 & 0.0824 & 0.7 & 0.30 & 0.997 \\
\hline \multicolumn{8}{|l|}{23} \\
\hline \multicolumn{8}{|l|}{24} \\
\hline \multicolumn{8}{|l|}{25} \\
\hline 26 & 1.505 & 0.0104 & 0.705 & 0.0176 & 22.3 & 7.02 & 0.983 \\
\hline 27 & 1.529 & 0.0347 & 0.740 & 0.0728 & 11.9 & 11.86 & 0.835 \\
\hline 28 & 1.537 & 0.0234 & 0.701 & 0.0592 & 15.6 & 17.12 & 0.822 \\
\hline 29 & 1.571 & 0.0157 & 0.684 & 0.0352 & 21.9 & 16.39 & 0.916 \\
\hline 30 & 2.257 & 0.0235 & 0.691 & 0.1408 & 4.4 & 8.96 & 0.565 \\
\hline 31 & 2.463 & 0.0231 & 0.619 & 0.1022 & 22.5 & 62.48 & 0.646 \\
\hline 32 & 2.231 & 0.0398 & 0.632 & 0.0629 & 37.7 & 55.34 & 0.767 \\
\hline 33 & 2.442 & 0.0300 & 0.565 & & 260.3 & 211.50 & 0.275 \\
\hline 34 & -3.218 & 124.5000 & 3.370 & 61.9127 & 0.7 & 16.10 & 0.887 \\
\hline 35 & 1.647 & 0.0136 & 0.756 & 0.0175 & 8.6 & 1.23 & 0.995 \\
\hline 36 & 1.044 & 48.5809 & 3.674 & 158.8000 & 0.1 & 5.43 & 0.864 \\
\hline \multicolumn{8}{|l|}{37} \\
\hline 38 & 1.908 & 0.0433 & 0.681 & 0.1950 & 4.0 & 10.06 & 0.705 \\
\hline 39 & 1.066 & 0.0092 & 0.688 & & 2.0 & 7.53 & 0.023 \\
\hline
\end{tabular}


Continued: SID-M+C model estimates using the quadratic broken-line model for minimum FCR

\begin{tabular}{lrrrrrrr}
\hline Trial Nr. & Estimate & StdErr & Estimate & StdErr & Estimate & StdErr & $\mathbf{R}^{\mathbf{2}}$ \\
& $\mathbf{L}$ & $\mathbf{L}$ & $\mathbf{R}$ & $\mathbf{R}$ & $\mathbf{U}$ & $\mathbf{U}$ & \\
\hline 40 & 1.065 & 0.0025 & 0.678 &. & 3.5 & 3.14 & 0.295 \\
41 & 1.083 & 0.0076 & 0.699 &. & 0.9 & 4.34 & 0.014 \\
42 & 0.976 & 7.5892 & 3.546 & 217.5000 & 0.0 & 0.98 & 0.350 \\
43 & 1.424 & 0.0053 & 0.664 & 0.0084 & 37.9 & 6.83 & 0.998 \\
44 & 1.413 & 0.0135 & 0.675 & 0.0190 & 31.2 & 11.45 & 0.983 \\
45 & 1.427 & 0.0050 & 0.685 & 0.0063 & 24.8 & 2.71 & 0.999 \\
46 & 1.428 & 0.0131 & 0.704 & 0.0212 & 18.3 & 6.03 & 0.987 \\
47 & 1.249 & 0.0245 & 0.680 & 0.0308 & 46.1 & 41.66 & 0.909 \\
48 & 1.202 & 0.0167 & 0.790 & 0.0301 & 8.0 & 2.64 & 0.986 \\
49 & 1.386 & 0.0118 & 0.696 & 0.0215 & 12.2 & 4.15 & 0.982 \\
50 & 1.437 & 0.0172 & 0.651 & 0.0332 & 20.4 & 16.03 & 0.901 \\
51 & 1.953 & 0.0206 & 0.635 & 0.0191 & 31.3 & 11.25 & 0.982 \\
52 & 1.947 & 0.0249 & 0.669 & 0.0285 & 18.1 & 7.72 & 0.974 \\
53 & 1.285 & 0.0032 & 0.972 & 0.0347 & 0.9 & 0.16 & 0.995 \\
55 & 1.328 & 0.0035 & 0.686 & & 4.4 & 1.34 & 0.845 \\
56 & 1.363 & 0.0084 & 0.752 & 0.0248 & 9.5 & 3.33 & 0.994 \\
57 & 1.413 & 0.0030 & 0.755 & 0.0063 & 13.0 & 1.12 & 1.000 \\
58 & 1.386 & 0.0048 & 0.751 & 0.0131 & 10.5 & 1.95 & 0.998 \\
59 & 1.204 & 0.0116 & 1.024 & 0.2647 & 0.3 & 0.51 & 0.443 \\
60 & 1.239 & 0.0109 & 1.079 & 0.1845 & 0.3 & 0.27 & 0.814 \\
61 & 1.105 & 0.0219 & 0.939 & 0.2311 & 1.0 & 1.73 & 0.388 \\
62 & 1.189 & 0.0089 & 0.960 & 0.1419 & 0.6 & 0.54 & 0.691 \\
\hline
\end{tabular}


SID-M+C model estimates using the quadratic broken-line model for maximum BWG

\begin{tabular}{|c|c|c|c|c|c|c|c|}
\hline Trial nr. & $\begin{array}{c}\text { Estimate } \\
\mathbf{L}\end{array}$ & $\begin{array}{r}\text { Std. Err. } \\
\text { L }\end{array}$ & $\begin{array}{r}\text { Estimate } \\
\mathbf{R}\end{array}$ & $\begin{array}{r}\text { Std. Err. } \\
\mathbf{R}\end{array}$ & $\begin{array}{r}\text { Estimate } \\
\mathbf{U}\end{array}$ & $\begin{array}{r}\text { Std. } \\
\text { Err. U }\end{array}$ & $\mathbf{R}^{2}$ \\
\hline 1 & 92.7 & 0.38 & 0.653 & 0.0157 & -526 & 104.9 & 0.992 \\
\hline 2 & 29.8 & 0.51 & 0.812 & 0.1677 & -53 & 75.2 & 0.864 \\
\hline 3 & 28.1 & 0.10 & 0.740 & 0.0173 & -125 & 26.0 & 0.995 \\
\hline \multicolumn{8}{|l|}{4} \\
\hline \multicolumn{8}{|l|}{5} \\
\hline 6 & 88.8 & 1.41 & 0.717 & 0.0680 & -524 & 493.2 & 0.852 \\
\hline 7 & 114.2 & 5.51 & 0.607 & 0.2908 & -1438 & 10453.8 & 0.155 \\
\hline 8 & 47.7 & 0.15 & 0.858 & 0.0096 & -164 & 11.4 & 0.999 \\
\hline 9 & 45.9 & 0.53 & 0.795 & 0.0345 & -264 & 85.2 & 0.988 \\
\hline 10 & 46.0 & 0.86 & 0.967 & 0.0710 & -208 & 131.3 & 0.932 \\
\hline 11 & 46.0 & 0.38 & 0.947 & 0.0237 & -328 & 75.4 & 0.991 \\
\hline 12 & 48.1 & 0.17 & 0.703 & 0.0067 & -631 & 52.3 & 0.999 \\
\hline 13 & 45.2 & 0.64 & 0.778 & 0.0365 & -252 & 78.1 & 0.988 \\
\hline 14 & 47.2 & 0.96 & 0.695 & 0.0397 & -665 & 339.4 & 0.963 \\
\hline 15 & 46.0 & 0.49 & 0.713 & 0.0271 & -413 & 131.1 & 0.988 \\
\hline 16 & 85.4 & 1.04 & 0.669 & 0.1125 & -215 & 284.5 & 0.824 \\
\hline 17 & 74.9 & 0.97 & 0.658 & 0.0827 & -301 & 310.4 & 0.891 \\
\hline 18 & 42.5 & 2.28 & 0.508 & 0.0525 & -505 & 217.0 & 0.930 \\
\hline 19 & 39.3 & 2.22 & 0.502 & 0.0494 & -539 & 222.5 & 0.936 \\
\hline 20 & 43.1 & 0.16 & 0.732 & 0.0195 & -194 & 54.8 & 0.983 \\
\hline 21 & 44.3 & 0.63 & 0.707 & 0.0286 & -706 & 345.8 & 0.956 \\
\hline 22 & 95.1 & 0.19 & 0.684 & 0.0338 & -120 & 57.1 & 0.986 \\
\hline \multicolumn{8}{|l|}{23} \\
\hline \multicolumn{8}{|l|}{24} \\
\hline \multicolumn{8}{|l|}{25} \\
\hline 26 & 34.9 & 0.40 & 0.733 & 0.0235 & -459 & 154.9 & 0.979 \\
\hline 27 & 31.7 & 0.61 & 0.753 & 0.0537 & -243 & 165.5 & 0.910 \\
\hline 28 & 34.1 & 0.11 & 0.769 & 0.0095 & -212 & 23.5 & 0.997 \\
\hline 29 & 30.9 & 0.05 & 0.696 & 0.0035 & -544 & 36.1 & 0.999 \\
\hline \multicolumn{8}{|l|}{30} \\
\hline 31 & 60.2 & 0.53 & 0.676 & 0.1539 & -112 & 274.6 & 0.490 \\
\hline 32 & 71.1 & 0.99 & 0.652 & 0.0667 & -623 & 806.7 & 0.769 \\
\hline 33 & 61.1 & 0.59 & 0.659 & 0.1279 & -180 & 422.6 & 0.501 \\
\hline \multicolumn{8}{|l|}{34} \\
\hline 35 & 68.0 & 1.15 & 0.712 & 0.0335 & -528 & 177.9 & 0.976 \\
\hline 36 & 66.6 & 1.75 & 0.750 & 0.2351 & -131 & 413.8 & 0.562 \\
\hline \multicolumn{8}{|l|}{37} \\
\hline \multicolumn{8}{|l|}{38} \\
\hline \multicolumn{8}{|l|}{39} \\
\hline 40 & 25.9 & 1.38 & 0.910 & 0.5801 & -21 & 82.0 & 0.397 \\
\hline 41 & 25.3 & 0.51 & 0.722 & & -200 & 154.0 & 0.359 \\
\hline 42 & 26.7 & 0.32 & 0.823 & 0.0701 & -83 & 62.1 & 0.931 \\
\hline 43 & 79.0 & 0.99 & 0.674 & 0.0152 & -2880 & 847.8 & 0.992 \\
\hline 44 & 78.3 & 1.76 & 0.667 & 0.0287 & -3270 & 1940.9 & 0.973 \\
\hline 45 & 70.1 & 1.14 & 0.664 & 0.0211 & -2701 & 1188.9 & 0.993 \\
\hline
\end{tabular}


Continued: SID-M+C model estimates using the quadratic broken-line model for maximum BWG

\begin{tabular}{lrrrrrrr}
\hline Trial Nr. & $\begin{array}{r}\text { Estimate } \\
\text { L }\end{array}$ & $\begin{array}{r}\text { StdErr } \\
\mathbf{L}\end{array}$ & $\begin{array}{r}\text { Estimate } \\
\mathbf{R}\end{array}$ & $\begin{array}{r}\text { StdErr } \\
\mathbf{R}\end{array}$ & $\begin{array}{r}\text { Estimate } \\
\mathbf{U}\end{array}$ & $\begin{array}{r}\text { StdErr } \\
\mathbf{U}\end{array}$ & $\mathbf{R}^{\mathbf{2}}$ \\
\hline 46 & 70.6 & 0.12 & 0.699 & 0.0024 & -1466 & 57.5 & 1.000 \\
47 & 28.6 & 1.63 & 0.856 & 0.1176 & -134 & 125.3 & 0.885 \\
48 & 29.7 & 0.26 & 0.827 & 0.0132 & -213 & 25.3 & 0.998 \\
49 & 76.5 & 1.58 & 0.696 & 0.0244 & -1438 & 553.1 & 0.977 \\
50 & 73.1 & 1.98 & 0.678 & 0.0308 & -1669 & 942.4 & 0.952 \\
51 & 95.8 & 1.36 & 0.638 & 0.0208 & -1830 & 699.5 & 0.979 \\
52 & 94.4 & 1.56 & 0.661 & 0.0298 & -1136 & 531.0 & 0.967 \\
53 & 41.0 & 0.15 & 0.955 & 0.0513 & -33 & 8.6 & 0.988 \\
55 & & & & & & & \\
56 & 33.9 & 0.75 & 0.739 & 0.1708 & -162 & 425.8 & 0.807 \\
57 & 56.6 & 0.93 & 0.907 & 0.0779 & -97 & 48.3 & 0.982 \\
58 & 34.8 & 0.88 & 0.913 & 0.1543 & -44 & 42.1 & 0.942 \\
59 & 15.8 & 0.10 & 0.985 & 0.1277 & -7 & 6.3 & 0.704 \\
60 & 28.0 & 0.07 & 0.770 & & -169 & 47.2 & 0.680 \\
61 & & & & & & & \\
62 & & & & & & & \\
\hline
\end{tabular}

